\title{
Note
}

\section{In Defense of the Civil Rights Remedy of the Violence Against Women Act}

\author{
Johanna R. Shargel
}

Because of gender-based violence, American women and girls are relegated to a form of second-class citizenship. . . . When half of our citizens are not safe at home or on the streets because of their sex, our entire society is diminished.

\section{- Sally Goldfarb, NOW Legal Defense and Education Fund'}

Violence currently poses the most significant threat to women's rights as equal citizens. The Senate Judiciary Committee, after reviewing a wide array of studies on violence against women in the United States, reported that "[v]iolence is the leading cause of injuries to women ages 15 to 44 , more common than automobile accidents, muggings, and cancer deaths combined."' Violence against women occurs with disturbing frequency and results in severe, often fatal, injuries. A recent Deparment of Justice survey reported that, in total, women aged twelve and older annually sustain almost five million violent victimizations; ${ }^{3}$ approximately five hundred thousand of these victimizations are rapes and sexual assaults." Rape in America, a

1. Crimes of Violence Motivated by Gender: Hearings on H.R. 1133 Before the Subcomm. on Cival and Constitutional Rights of the House Comm on the Judictan: 103d Cong. 7-S (1993) [hereınafter Crumes of Violence] (statement of Sally Goldfarb. Senior Staff Attomey. NOW Legal Defense and Education Fund).

2. S. REP. NO. 103-138, at 38 (1993).

3. See Ronet Bachman \& linda E. Saltzaial. U.S. Dep't of Jlstice VIOleNce against WOMEN: ESTIMATES FROM THE REDESIGNED SURVEY 2 (1995). According to the Natuonal Cnme Victimization Survey (NCVS), "violent victimizations" include homicide, rape/sexual assault, robbery. aggravated assault, and simple assault. See id.

4. See id. Note that the 1995 NCVS implemented significant methodological changes pursuant to an extensive 10-year redesign project aimed at producing more accurate reporting of incidents of rape and sexual assault. See id. at 1.

5. National Victim Center \& Crime Victims ResearÇH aNd Treatmient CEuter. Rape in AMERICA: A REPORT TO THE NATION (1992) [hereunafter RAPE IN AMERICA] 
comprehensive national study, found that one out of every eight adult women has been the victim of forcible rape at some point in her lifetime. ${ }^{6}$

Until recently, women victimized by the reality or threat of violence were left without an effective remedy, and therefore denied their right to full and equal citizenship. First, the disabling physical and psychological effects of violence have kept women from participating as commercial actors, and their absence from the nation's marketplace has had a substantial effect on interstate commerce. Women have, in Goldfarb's words, been "relegated to a form of second-class citizenship" because violence has prevented them from contributing to the national economy on an equal footing with men. ${ }^{7}$ Women have also been "relegated to a form of second-class citizenship" because state criminal justice systems have frequently denied female victims of violence their right to equal protection of the laws. ${ }^{8}$ Because both the restrictive letter and the biased implementation of state laws have failed to keep women "safe at home or on the streets," women continually have been deprived of their full citizenship rights.

In September 1994, Congress passed the Violence Against Women Act (VAWA), ${ }^{9}$ drafted in response to what its chief legislative sponsor, Senator Joseph R. Biden, called a "national tragedy."10 The law evolved gradually over a four-year period during which Congress heard testimony from women's rights and civil rights organizations, state attorneys general, law professors, law enforcement officials, physicians, and victims of violence. What emerged from this expert testimony is a comprehensive statute containing a wide range of provisions designed to address the pressing problem of violence against women.

For example, to improve overall safety for women, the VAWA increases penalties for federal rape convictions and provides state grants to support law enforcement and educational efforts aimed at reducing violent crime against women. "With respect to domestic violence, the Act criminalizes interstate domestic violence, ${ }^{12}$ and ensures that a protective order issued in one state is given "full faith and credit" in all other states. ${ }^{13}$ In an effort to achieve equal justice for women in the courts, the Act authorizes grants to improve the training of judges who deal with issues involving domestic violence and also encourages circuit judicial councils to conduct gender bias studies. ${ }^{14}$

6. See id. at 2.

7. See infra Section I.A.

8. See infra Section II.A.

9. The Violence Against Women Act of 1994, Pub. L. No. 103-322, Title IV, 108 Stat. 1902 (codified as amended in scattered sections of 8,18 and 42 U.S.C.). The bill was enacted as part of the Violent Crime Control and Law Enforcement Act of 1994, Pub. L. No. 103-322.

10. S. REP. NO. 102-197, at 39 (1991).

11. See 28 U.S.C. $\$ 994$ (1994); 42 U.S.C. $\$ 3796 \mathrm{gg}$ (1994).

12. See 18 U.S.C. $\$ \$ 2261-62$ (1994).

13. See id. § 2265 .

14. See 42 U.S.C. $\$ \S 13991-4002$. 
Without question, the most controversial provision of the VAWA is the section entitled "Civil Rights for Women." 15 This provision establishes a federal civil rights cause of action for victims of violent crimes "motivated by gender." would be a federal or state felony, whether or not the offense has actually resulted in criminal charges, prosecution, or conviction. ${ }^{17}$ Under the statute, a person who commits a crime of gender-motivated violence, whether a public or private actor, is liable to the injured party and subject to compensatory and punitive damages, as well as injunctive and declaratory relief. ${ }^{18}$

The VAWA Civil Rights Remedy is based on two independent constitutional sources of legislative authority: the Commerce Clause and the Fourteenth Amendment's enforcement provision, Section Five. Since the Remedy was passed, two federal district courts have considered challenges to

15. Id. $\S 13981$. For a description of the controversy surrounding the VAWA Remedy"s enactment, see Victoria F. Nourse, The Violence Against Women Act: A Legislatwe Histony. in VIOLENCE AGaisst WOMEN: LAW \& PRACTICE (forthcoming Mar. 1997) (manuscnpt at 37-40. on file with the Yale Low Journal). Nourse explains that opposition arose primarily from federal and state judges. including Chief Justice William Rehnquist. See id. at 37-38. For the most part. critues wamed that the Remedy would "flood" federal courts with claims of gender-motivated violence. Sec. e.g. REPORT OF THE JUDICLAL CONFERENCE AD HOC COMMITTEE ON GENDER-BASED VIOLENCE 6 (1991). It is highly unlikely, however. that this concem would ever materialize. First, virtually every statustueal study on volence agaunst women has found that it is vastly underreported. See. e.g.. RAPE IN AMIERICA. supra note 5. al 6 (estumalung that only $16 \%$ of all rapes are ever reported). Furthermore, sexual assault clams currently represent only a small fraction of all civil cases filed. See Crimes of Violence, supra note 1. at 11 (statement of Sally Goldfarb. Senior Staff Attomey, NOW Legal Defense and Education Fund) (citung study by Jury Verdıct Research. Inc., reporting only 255 civil jury trials in sex assault cases over 10-year penod).

16. 42 U.S.C. $\$ 13981$. According to the statute, a gender-molivated crime is "committed because of gender or on the basis of gender, and due, at least in par, to an animus based on the vicum's gender." Id. $\S 13981$ (d)(1). The injured party must demonstrate by a preponderance of the evidence that the cnme was motivated by gender. See id. $\$ 13981$ (e)(1). To date, there have been no final judgments on clams brought under the VAWA Civil Rights Remedy, and so no court has yel ruled on the meaning of the term "gendermotivated." Many feminist legal scholars interpreting the VAWA Remedy posit that the large majonty of violent crimes against women are gender-mouvated. See, e.g., Bırgit Schmidt Am Busch. Domestuc Violence and Title III of the Violence Against Women Act of 1993: A Feminust CnItque. 6 Hastwas WOMEN's LJ. 1, 13-19 (1995) (arguing that courts should create rebuttable presumption that crime was gender-motivated). W.H. Hallock, Note, The Violence Against Women Act: Civil Rights for Sexual Assault Vicums. 68 IND. LJ. 577, 579 (1993) (maintaining that sexual assault and domestic violence are cnmes predominantly motivated by gender). Moreover, an early version of the VAWA Remedy incorporated the presumption that crimes of violence against women are gender-motivated. See Sally Goldfarb. The Curl Rights Remedy of the Violence Against Women Act: Legislative History; Policy Implications \& Litigation Strategy, \& J.L \& POL'Y 391, 396 (1995) (quoting H.R. 1502, 102d Cong. (1991)). This Note adopts this vew, and therefore uses the phrases "violence against women" and "gender-motivated volence" interchangeably throughout. As an aside, it is interesting to note that the only case to date to invalidate the VAWA Civil Rughts Remedy, Brzonkala v. Virginia Polytechnic \& Stale Universın. 935 F. Supp. 779 (W.D. Va. 1996), also used the terms "violence against women" and "gender-mouvated volence" interchangeably. Compare, e.g . id. at 789 ("[C]ongressional findings which support that volence aganst women affects interstate commeree are currently before this Court."), with id. at 800 ("Congress's purpose to remedy discriminanton by pnvate individuals who commit gender-based violent crime against a woman is an illegitumate Fourteenth Amendment end .....").

17. See 42 U.S.C. § 13981(d)(2). If there has not been a cnminal convicuon. "The cival nghts action will involve a hearing in which the elements of the felony must be proved by a preponderance of the evidence." Julie Goldscheid \& Susan J. Kraham. Act Provides Cavil Remedy for Violence. NaT'L Lu. May 1,1995 , at B9, B10.

18. See 42 U.S.C. \& 13981 (c). 
the constitutional validity of the statute, ruling in opposite directions. In Doe v. Doe,$^{19}$ a Connecticut district court upheld the Remedy, concluding that it constitutes a legitimate exercise of Congress's power to regulate interstate commerce. ${ }^{20}$ Only one month later, in Brzonkala v. Virginia Polytechnic \& State University, ${ }^{21}$ a Virginia district court invalidated the VAWA civil rights law, holding that the enactment exceeds Congress's authority under both the Commerce Clause and Section Five of the Fourteenth Amendment. ${ }^{22}$

This Note defends the constitutionality of the VAWA Civil Rights Remedy, which is currently mired in controversy and doctrinal confusion. Part I examines the Commerce Clause ground of the Remedy, focusing on United States v. Lopez, ${ }^{23}$ a postenactment Supreme Court decision that, in another context, narrowed Congress's commerce power, thereby raising questions about the constitutional legitimacy of the VAWA Remedy. Part II analyzes the Section Five basis for the Remedy, arguing against claims that the statute fails to meet the Fourteenth Amendment's state action requirement. Although the constitutional attacks on the VAWA civil rights law are formidable, particularly with respect to the Commerce Clause, this Note concludes that the case law interpreting both constitutional provisions largely supports the Remedy's legitimacy on both interstate commerce and equal protection grounds.

\section{SURVIVING LOPEZ: THE SUBSTANTIAL EFFECT OF GENDER-MOTIVATED VIOLENCE ON INTERSTATE COMMERCE}

In 1994, when the Violence Against Women Act was passed, the Commerce Clause appeared to be a sound basis for congressional action. ${ }^{24}$ The Supreme Court had not invalidated legislation relying on the Commerce Clause in nearly sixty years, ${ }^{25}$ and case law consistently granted tremendous deference to congressional regulations designed to protect interstate commerce. ${ }^{26}$ In 1995, however, the Lopez Court struck down a statute with a tenuous connection to interstate commerce, thereby redefining the scope of congressional power under the Commerce Clause. ${ }^{27}$ Cautioning that Congress

19. 929 F. Supp. 608 (D. Conn. 1996).

20. See id. at 617 .

21. 935 F. Supp. 779 (W.D. Va. 1996).

22. See id. at 801 .

23. 115 S. Ct. 1624 (1995).

24. See 42 U.S.C. $\S 13981$ (a) (1994). The Constitution grants Congress the power "[t]o regulate Commerce with foreign Nations, and among the several States, and with the Indian Tribes." U.S. CONST. art. I, \& 8 .

25. Before Lopez, the Court had not struck down a statute passed under the Commerce Clause since 1935, see A.L.A. Schechter Poultry Corp. v. United States, 295 U.S. 495, 549-50 (1935), except in National League of Cities v. Usery, 426 U.S. 833 (1976), which was subsequently overruled in Garcia v. San Antonio Metropolitan Transit Authority, 469 U.S. 528, 557 (1985).

26. See infra Subsection I.B.1.

27. See Lopez, 115 S. Ct. 1624. 
would no longer have free rein in the commerce arena, the Lopez Court ruled that unless the legislation pertained to the channels or instrumentalities of interstate commerce, Congress would only be permitted to regulate activities that substantially affect interstate commerce. ${ }^{28}$ In addition, the Lopez Court frowned on the regulation of intrastate activity that lacks a concrete tie to interstate commerce; it also viewed with disapproval legislation that targets noncommercial activity. Lopez, however, is a deeply ambiguous opinion that has generated a considerable amount of doctrinal uncertainty both in lower courts and among academic commentators.

This Part analyzes the impact of Lopez on Commerce Clause jurisprudence in general and on the constitutionality of the VAWA Civil Rights Remedy in particular. It concludes that although Lopez poses a number of troubling questions and casts some doubt on Congress's authority to enact the VAWA Remedy, the Remedy will most likely survive Lope: ${ }^{29}$ The first Section of this Part examines the damaging effect of gender-motivated violence on interstate commerce. The second Section analyzes the Lopez decision and its impact on the otherwise uniformly deferential Commerce Clause case law of the modern era and concludes that the VAWA Civil Rights Remedy remains well-grounded in the Commerce Clause.

\section{A. Violence Against Women: A Well-Documented and Substantial Threat to Interstate Commerce}

Voluminous testimony at the congressional hearings on the VAWA Civil Rights Remedy evidenced the tremendous strain that violence against women imposes on the nation's productive capacity, clearly demonstrating that gendermotivated violence has a substantial effect on interstate commerce. As the Senate Judiciary Committee summarized: "Gender-based crimes and the fear of gender-based crimes restrict movement, reduce employment opportunities, increase health expenditures, and reduce consumer spending, all of which affect interstate commerce and the national economy." 30 Extensive congressional findings and other studies demonstrate that gender-motivated violence has a detrimental effect on interstate commerce.

First, gender-motivated violence severely limits women's contribution to the national economy. Over thirty years ago, when enacting Title VII of the

28. The Lopez Court promulgated this standard as a clarification of its carlier case law; which. by its own admission, "ha[d] not been clear whether an activity must 'affect' or 'substantually affect" interstate commerce in order to be within Congress' power to regulate tt under the Commerce Clause." Id. at 1630

29. A note recently published in the Columbia Low' Review analyzes the VAWA Civil Rights Remedy in light of Lopez and determines that the Remedy still consututes a leguumate exercise of Congress's Commerce Clause powers. See Kerrie E. Maloney. Note, Gender-Mornated Violence and the Commerce Clause: The Civil Rights Provision of the Violence Against Women Act After Lopez. 96 COLUM. L. REV 1876 (1996).

30. S. REP. NO. 102-197, at 53 (1991). 
1964 Civil Rights Act, Congress sought to guarantee equal opportunity for women in employment. ${ }^{31}$ Gender-motivated violence, however, defeats the purpose and benefit of Title VII; it physically prevents millions of American women from full participation in commercial activity. Domestic violence in particular significantly impairs job performance: Victims of domestic violence are often harassed by their batterers at work, prevented from arriving to work on time, and kept from attending work altogether because of serious injuries. ${ }^{32}$ Moreover, the threat of violence affects women's employment decisions and conduct to a large extent: Fear of violence deters women from applying for or accepting job positions in unsafe neighborhoods, and it discourages women from working after dark or on weekends. ${ }^{33}$ The fear and threat of violence affect every American woman and therefore have both an inevitable and an enormous impact on interstate commerce.

Gender-motivated violence not only deprives women of employment opportunities, but also has a significant effect on business nationwide. At the VAWA congressional hearings, experts on abuse and legal scholars described how gender-motivated violence depletes the nation's workforce. As New York University law professor Burt Neuborne explained:

In pure economic terms, the sheer loss of productivity attributable to violent gender-based assault is staggering .... The dislocation of the nation's labor force that is caused by fear of violent gender-based

31. See 42 U.S.C. $\$ 2000$ (e) (1994). Title VII, like the VAWA Civil Rights Remedy, was based on Congress's Commerce Clause power, recognizing that bias in the workplace creates a massive drain on the nation's productive capacity. See, e.g., 110 CONG. REC. 6548 (1964) (statement of Rep. Humphrey). Because gender-motivated violence has a comparable impact on the national economy, the Civil Rights Remedy should be sustained by the same logic. See Crimes of Violence, supra note 1, at 43 (statement of Burt Neuborne, Professor of Law, New York University) (analogizing Civil Rights Remedy to Title VII and maintaining that Remedy is "equally supported by a need to eradicate the destructive effects of gender bias from our economic system"); Nourse, supra note 15, at 6 ("Would a law guaranteeing equal pay mean much to a woman whose husband beat her when she left the house? . . . Violence against women . . . could wipe out in a single blow any and every advance in opportunity created by over twenty years of law reform."). Note, however, that it can be argued that Lopez drew a line between statutes like Title VII, which directly regulate employment or economic activity, and statutes like the VAWA Civil Rights Remedy, which regulate noncommercial conduct that affects interstate commerce. According to this broad reading of Lopez, regulation of noncommercial, intrastate activity would be constitutionally impermissible. See infra Section I.B.

32. See JODY RAPHAEL, TAYLOR INSTTIUTE, PRISONERS OF ABUSE: DOMESTIC VIOLENCE AND WELFARE RECEIPT 6-8, 15 (1990) (citing anecdotal and statistical evidence of effect of battering on employment status of women); Melanie Shepard \& Ellen Pence, The Effect of Battering on the Employment Status of Women, 13 AFFILA 55, 58 (1988) (finding that one-quarter of battered women surveyed had lost job due at least in part to effects of domestic violence, and over half were harassed by their abusers at work); Connie Stanley, Domestic Violence: An Occupational Impact Study 17 (July 27, 1992) (unpublished manuscript, on file with the Yale Law Journal) (finding that over $70 \%$ of employed battered women are subject to telephone harassment at work by their abusers; over $60 \%$ are late to work because of their abuser; over $50 \%$ miss work because of abuse; and $70 \%$ have difficulty performing their job because of their abusive situation).

33. See Violence Against Women: Victims of the System: Hearings on S. 15 Before the Senate Comm. on the Judiciary, 102d Cong. 240-41 (1991) (statement of Elizabeth Athanasakos, National President, National Federation of Business and Professional Women, Inc.). 
assault is enormous: women who do not enter or who leave the labor force because of fear; women whose choice of job is dictated by fear; women whose performance on the job is affected by fear. ${ }^{3 .}$

Due to the prevalence of violence against women, employers across the country must contend with lost productivity, increased health-care and security costs, and higher turnover. ${ }^{35}$

In addition to decreasing nationwide production, violence against women also has a negative effect on levels of commercial consumption. As one witness explained at the VAWA congressional hearings:

Women who cannot traverse public streets without fear will also not use places of public accommodation, purchase goods, or conduct business in such areas. Fear of gender-motivated violence restricts the hours during which women can engage in a variety of activities and seriously curtails their participation in the commerce of our nation. ${ }^{36}$

Whether analyzing the economic loss precipitated by gender-motivated violence from the perspective of supply or demand, the conclusion is the same: Gender-motivated violence affects interstate commerce because women as a group constitute approximately half the nation's consumers and producers. The fact that the VAWA Civil Rights Remedy is rooted in the Commerce Clause rightly acknowledges that when half the citizens of this country-half the commercial actors-either fear or are subject to incapacitation by violence because of their gender, the entire nation suffers.

\section{B. United States v. Lopez: An Uncertain Legacy}

As described in the previous Section, there is more than adequate data demonstrating the significant costs of violence against women to suppor the claim that gender-motivated violence substantially affects interstate commerce.

34. Crimes of Violence, supra note 1, at 43 (statement of Burn Neubome. Professor of Law: New York University); see also Martha F. Davis \& Susan J. Kraham. Prolectung Women's IVelfare in the Face of Violence, 22 ForDHAM URB. L.J. 1141, 1142-44 (1995) (explaining how volence prevents poor women from participating in welfare-to-work programs and therefore prevents many women from obtanning and maintaining employment): Jason DeParle, Welfare Mothers Find Jobs Are Easter to Get Than Hold. X.Y TIMES, Oct. 24, 1994, at Al (noting that abusive boyfriends interfere with women's employment when they feel "threatened by the prospect of [the woman's] independence")

35. See, e.g., Hearing on Domestic Violence: Hearing on S. 596 Before the Senate Comm on the Judiciary, 103d Cong. 15 (1993) (statement of James Hardeman. Manager of Employec Assistance Program, Polaroid Corp.); Joan Zorza, Women Battering: High Cosis and the State of the Low. 28 CLEARINGHOUSE REV. 383, 383-86 (1994) (documenting costs of violence against women in terms of medical resources, employment, and law enforcement): The Billon Dollar Epidemic, Ast MED. NEwS, Jan. 6, 1992 (reporting that family violence costs nation about " $\$ 5$ to $\$ 10$ billon a year"): Milt Freudenheım. Employers Act to Stop Family Violence, N.Y. TIMES, Aug. 23. 1988, at Al; Joseph Pereire. Employers Confront Domestic Abuse, WALL ST. J., Mar. 2. 1995. at B1.

36. Crimes of Violence, supra note 1, at 109 (statement of James P. Tumer. Actung Assistant Attomey General of the Department of Justice's Civil Rights Divisıon). 
Turning to the relevant body of case law, the question becomes whether the nexus between gender-motivated violence and interstate commerce is sufficiently close to meet the standards established in United States v. Lopez, ${ }^{37}$ the Supreme Court's most recent and most restrictive formulation of Congress's Commerce Clause power. In Lopez, the Court departed significantly from its traditional approach to legislation enacted under the Commerce Clause, suggesting that Congress's commerce power is constrained by certain limiting principles. Lopez, however, is an ambiguous case that raised more questions than it answered. Since Lopez was decided, lower courts and academic commentators have grappled with the issues presented by the decision, and have reached contradictory conclusions. The doctrinal uncertainty generated by Lopez is demonstrated by the fact that the two district courts that have reviewed the constitutionality of the VAWA Civil Rights Remedy after Lopez have ruled in opposite directions. ${ }^{38}$ Although the Lopez Court offered certain indications that it would regard specific types of congressional regulation with less favor, it did not establish a rigid standard or bright-line test for evaluating the validity of commerce legislation. ${ }^{39}$ Ultimately, the VAWA Civil Rights Remedy would fail only under the most expansive reading of Lopez, a reading that does not seem to be the most plausible or defensible construction of the case.

Lopez invalidated the Gun-Free School Zones Act of 1990, an act that made possession of a firearm in a school zone a federal offense. ${ }^{40}$ The Court held that the statute exceeded Congress's commerce power because the possession of firearms in school zones does not qualify as economic activity that substantially affects interstate commerce. ${ }^{41}$ After reviewing the history of Commerce Clause jurisprudence in some detail, the Lopez Court identified three broad categories of activity that Congress is permitted to regulate under its commerce authority: first, "the use of the channels of interstate commerce"; second, "the instrumentalities of interstate commerce, or persons or things in interstate commerce"; and third, "those activities that substantially affect interstate commerce." ${ }^{.42}$ With respect to the Gun-Free School Zones Act, the Court "quickly disposed" of the first two categories and focused its attention on the third, finding that the possession of guns in local school zones does not "substantially affect[] interstate commerce." ${ }^{\text {43 }}$ Recognizing that prior Commerce Clause cases had granted "great deference to congressional action,"

\footnotetext{
37. 115 S. Ct. 1624 (1995).

38. See supra text accompanying notes 19-22.

39. The Lopez Court admitted: "[C]ongressional power under the Commerce Clause "is necessarily one of degree.' . . . These are not precise formulations, and in the nature of things they cannot be." $115 \mathrm{~S}$. Ct. at 1633-34 (citation omitted).
}

40. See id. at 1626.

41. See id. at 1634.

42. Id. at 1629-30.

43. Id. at $1630-31$. 
the Lopez Court determined that it was time to distinguish between "what is truly national and what is truly local." According to the Lopez Cour, the Gun-Free School Zones Act presented an ideal line-drawing opportunity, as the Act apparently had "nothing to do with 'commerce' or any sort of economic enterprise, however broadly one might define those terms." Ns

Lopez left two significant questions in its wake: whether legislation enacted under the Commerce Clause requires a jurisdictional element and whether such legislation is restricted to the regulation of economic or commercial activity. If future Supreme Court opinions resolve these questions in accordance with the broadest possible reading of Lopez, the result could be fatal to the VAWA Civil Rights Remedy. The text of the Lopez opinion itself, as well as its interpretation by lower courts and legal academics, however, favor a more moderate reading of Lopez-one that would leave the VAWA Remedy unscathed.

\section{The Jurisdictional Element}

With respect to the first open-ended and potentially damaging issue, the necessity of a jurisdictional element, the Lopez Cour was troubled by the fact that the Gun-Free School Zones Act had "no express jurisdictional element which might limit its reach to a discrete set of firearm possessions that additionally have an explicit connection with or effect on interstate commerce." ${ }^{\text {"46 }}$ The specific facts of Lopez show the marked absence of a concrete tie to interstate commerce: "Respondent was a local student at a local school; there is no indication that he had recently moved in interstate commerce ... ." ${ }^{47}$ In reviewing the VAWA Remedy after Lopez, the Court might similarly conclude that gender-motivated violence is principally local conduct that lacks a cognizable tie to interstate commerce. At bottom, the Civil Rights Remedy, like the Gun-Free School Zones Act, does not contain a jurisdictional element ensuring on a case-by-case basis that each alleged violation of the Remedy affects interstate commerce. ${ }^{48}$ Under the Remedy, prosecution may be brought in a case where neither the perpetrator nor the victim has ever crossed a state line.

Some lower courts interpreting Lopez have emphasized the significance of the jurisdictional element in determining whether a particular activity substantially affects interstate commerce. For example, in upholding the federal

44. Id. at 1634

45. Id. at $1630-31$.

46. Id. at 1631 .

47. Id. at 1634 .

48. The Brtonkala court emphasized this argument, mantaining that the VAWA Cival Rights Remedy. like the Gun-Free School Zones Act, "does not have a junsdictional requirement limiung each individual case under VAWA to situations involving interstate commerce." Brzonkala v. Virgina Polytechnic \& Stale Univ., 935 F. Supp. 779, 792 (W.D. Va. 1996). 
carjacking statute against a post-Lopez Commerce Clause challenge, the Third Circuit appeared to be influenced considerably by the fact that the carjacking statute, unlike the Gun-Free School Zones Act, "contains a "jurisdictional element' which ostensibly limits its application to activities substantially related to interstate commerce. ${ }^{39}$ The court pointed out that the text of the carjacking statute guaranteed the necessary interstate nexus by requiring proof that the victim's motor vehicle "'ha[d] been transported, shipped or received in interstate or foreign commerce.", 50

Other lower courts interpreting Lopez have utilized a looser, more flexible approach to the jurisdictional element issue. For example, although the Freedom of Access to Clinic Entrances Act of 1994 (FACE) $^{51}$ does not contain a jurisdictional element within the text of the statute itself, six lower courts reviewing the statute after Lopez have found that the statute includes the requisite tie to interstate commerce. ${ }^{52}$ Courts defending FACE against Lopez challenges have relied on the fact that "individuals travel interstate to obtain and provide reproductive health services," so that the obstruction of those services tangibly interferes with interstate commerce. ${ }^{53}$ In fact, courts have noted that violence at clinics increases the necessity of interstate travel by decreasing the availability of reproductive health services nationwide. ${ }^{54}$ One court reviewing a Commerce Clause challenge to FACE also found a viable interstate nexus because "the effort to close reproductive health facilities is organized on a national scale." 55 Because of this concrete evidence that the provision of reproductive health services inherently contains a jurisdictional element, that court concluded that clinic obstruction presents a "truly interstate problem" rather than a "multistate, intrastate problem." 56

While the federal carjacking statute includes a literal jurisdictional element and FACE contains a jurisdictional element in an interpretive sense, some statutes ruled constitutional after Lopez do, not have jurisdictional ties at all. For example, the Drug Free School Zones Act bears no textual mention of interstate commerce and has been upheld by several circuits after Lopez. ${ }^{57}$

49. United States v. Bishop, 66 F.3d 569, 585 (3d Cir. 1995), cert. denied, 116 S. Ct. 681 (1995); accord United States v. Robinson, 62 F.3d 234, 237 (8th Cir. 1995); United States v. Oliver, 60 F.3d 547, 550 (9th Cir. 1995).

50. Bishop, 66 F.3d at 585 (quoting 18 U.S.C. $\$ 2119$ (1994)).

51. 18 U.S.C. § 248 (1994).

52. See, e.g., United States v. Dinwiddie, 76 F.3d 913, 919-21 (8th Cir. 1996); United States v. Wilson, 73 F.3d 675 (7th Cir. 1995), cert. denied, 117 S. Ct. 47 (1996); Cheffer v. Reno, 55 F.3d 1517, 1520-21 (11th Cir. 1995); United States v. Scott, 919 F. Supp. 76, 78-79 (D. Conn. 1996); United States v. Lucero, 895 F. Supp. 1421, 1423-24 (D. Kan. 1995); United States v. White, 893 F. Supp. 1423, 1433-34 (C.D. Cal. 1995).

53. Wilson, 73 F.3d at 681 .

54. See, e.g., id.

55. Id. at 683 .

56. Id.

57. See United States v. Zorrilla, 93 F.3d 7, 8-9 (1st Cir. 1996); United States v. Tucker, 90 F.3d 1135, 1139-41 (6th Cir. 1996); United States v. Rogers, 89 F.3d 1326, 1338 (7th Cir. 1996). Other postLopez cases and commentary indicate that a jurisdictional element is not a prerequisite of constitutionality. 
Furthermore, none of the courts upholding the Drug Free School Zones Act has even attempted to construct a quasi-jurisdictional element in the way that courts upholding FACE have done. Evidently, there is widespread uncertainty over what constitutes a jurisdictional element, and whether one is necessary to pass constitutional muster after Lopez. As the Brzonkala cour pointed out, "it is unclear whether such a jurisdictional requirement is needed."ss

Prior to Lopez, the concept of a jurisdictional element did not present itself in Commerce Clause case law. Over the past sixty years, in a series of highly deferential decisions, the Court allowed Congress free rein to regulate purely intrastate activity as long as that activity had a sufficient effect on interstate commerce when considered in the aggregate. ${ }^{59}$ Although Lopez, with its explicit reference to a jurisdictional element, appears to have introduced a more stringent standard for determining whether the activity at issue has an adequate interstate nexus, the Court also specifically noted that its decision would preserve Commerce Clause precedent in its entirety. The final passage in Lopez clearly states that the Court simply declined "to proceed any furher" down the road toward granting Congress "general police power." 60 The Lopez Court therefore expressed only an intent to limit the expansion of congressional commerce power, not an intent to retract authority granted to Congress in previous cases. Because the Lopez opinion claims to be in harmony with a long lineage of deferential Commerce Clause cases, it is these cases that must be brought to bear in interpreting Lopez and in determining the extent to which a jurisdictional element or interstate nexus will be required of legislation enacted under the Commerce Clause.

See, e.g., United States v. Taylor, 897 F. Supp. 1500 (D. Conn. 1995) (upholding statute prohibiung sale or transfer of firearm to felon); United States v. Gonzalez, 893 F. Supp. 935 (S.D. Cal. 1995) (upholdıng drug distribution statute); see also Maloney, supra note 29. at 1932 ("[T] Lo Lope: Coun did not announce that every future statute must contain a jurisdictional element.").

58. Brzonkala v. Virginia Polytechnic \& State University, 935 F. Supp. 779.792 (W.D. Va. 1996).

59. See cases discussed infra text accompanying notes 61-81. Man) post-Lopez law review anticles describe how Lopez broke with a half-century tradition of deferencial Commerce Clause case law. See. e.g. Russell L. Weaver, Lopez and the Federalization of Crmmal Law. 98 W. VA. L REv. 815.819 (1996) ("In United States v. Lopez, for the first time in nearly six decades, the judiciary reassented itself."): Stephen Christopher Likes, Casenote, An Unter Disregard for Precedent: Misconstrutung Commerce Clause Precedens in United States v. Lopez, 29 CREIGHTON L. REV. 811,843 (1996) (analyzing Lopez in light of fact that "[f]or almost sixty years, the Court has taken a "hands-off" approach to regulauons promulgated under the Commerce Clause .....").

60. 115 S. Ct. 1624, 1634 (I995) (citation omitted); see also id. at 1636-37 (Kennedy. J., concumng) (concluding, after reviewing history of Commerce Clause jurisprudence. that major precedents "are not called in question by our decision today"). Even Justice Thomas, whose concurnng opinion nued the "wrong tum" the Court took in the 1930s, conceded that many believe "it is too late in the day to undertake a fundamental reexamination of the past 60 years. Consideration of stare decisis and reliance interests may convince us that we cannot wipe the slate clean." Id. at 1650 n.8 (Thomas. J., concumng). It is also worth noting that a Seventh Circuit post-Lopez decision upholding the Freedom of Access to Clinic Entrances Act against a Lopez challenge concluded that, "the Supreme Coun reaffimed, rather than overumed, the previous half century of Commerce Clause precedent in Lopez. . . Because the Supreme Court lefit intact Jones \& Laughlin and all its progeny ... it obviously did not intend Lopez to be a depanture from established Commerce Clause precedent." Wilson. 73 F.3d at 685. 
The Court's generous, hands-off approach to Congress's Commerce Clause authority began in 1937 with $N L R B$ v. Jones \& Laughlin Steel Corp., ${ }^{61}$ a decision upholding the National Labor Relations Act of $1935 .{ }^{62}$ On its face, the Act regulated purely intrastate activity; its aim was to protect the rights of employees to unionize. Nevertheless, the Court found that the local manufacturing operations of the Pennsylvania steel company at issue, a company that received raw materials from other states and shipped finished products interstate, had "such a close and intimate relation to interstate commerce as to make the presence of industrial strife a matter of the most urgent national concern." ${ }^{63}$ Extending exceptionally broad power to Congress, the Court explained that the commerce authority "is not limited to transactions which can be deemed to be an essential part of a 'flow' of interstate or foreign commerce." ${ }^{64}$ According to the Jones \& Laughlin Steel Court, Congress is free to regulate an intrastate activity outside the regular flow of interstate commerce as long as the activity has a "close and substantial relation" to interstate commerce, and its regulation is necessary to protect interstate commerce against "burdens and obstructions." 65

In cases following Jones \& Laughlin Steel, the Court continued to blur the distinction between interstate and intrastate activity, granting ever-increasing power to Congress to regulate intrastate activity. In United States v. Darby, ${ }^{66}$ for example, the Court upheld the Fair Labor Standards Act of 1938, an act prohibiting the interstate shipment of commodities produced under labor conditions that violate certain federal standards. A unanimous Court held that Congress is permitted to regulate local labor conditions, a purely intrastate subject, so long as the finished product would ultimately be sold interstate. ${ }^{67}$ The Court further held that even where only a portion of goods produced is intended for interstate commerce, Congress may still regulate the entire industry because products intended for interstate commerce are, in practice, inseparable from products intended for intrastate commerce. Like the Jones \& Laughlin Steel Court before it, the Darby Court rendered the line between interstate and intrastate activity virtually indistinct, approving federal regulation of intrastate activity that substantially affects interstate commerce in a broad sense.

In Wickard v. Filburn, ${ }^{68}$ the Court reached the high-water mark of its deference to Congress's power to regulate intrastate activity under the Commerce Clause. Wickard involved a challenge to the Agricultural

61. 301 U.S. 1 (1937).

62. See id. at 30 .

63. Id. at 41 .

64. Id. at 36

65. Id. at 37 .

66. 312 U.S. 100 (1941).

67. See id. at 123.

68. 317 U.S. 111 (1942). 
Adjustment Act of $1938,{ }^{69}$ an act that imposed quotas on wheat to increase its market price. The plaintiff in Wickard was an Ohio farmer who operated a small dairy farm that produced wheat solely for consumption on the farm itself. ${ }^{70}$ According to the Wickard plaintiff, the Agricultural Adjustment Act, as applied in his case, exceeded Congress's commerce power because it regulated activities "local in character" that had only an "indirect" effect on interstate commerce." Writing for a unanimous Court, Justice Jackson rejected the plaintiff's challenge to the Act, reasoning that the fact that the plaintiff's "own contribution to the demand for wheat may be trivial by itself is not enough to remove him from the scope of federal regulation where, as here, his contribution, taken together with that of many others similarly situated, is far from trivial." "While the Darby Cour had held that Congress could control intrastate activity where it is "inseparable" from interstate activity, the Wickard Court took Congress's power one step further and held that Congress could regulate purely intrastate activity-here, a farmer's consumption of his own homegrown wheat-because that activity has a substantial effect on interstate commerce when considered in the aggregate. ${ }^{73}$

Looking to the permissive holdings of Jones \& Laughlin Steel and its progeny, which indicated that the Cour was prepared to accord Congress substantial freedom to regulate intrastate activity, Congress decided to rely on the Commerce Clause as the constitutional basis for Tite II of the Civil Rights Act of 1964. Title II prohibits racial discrimination in places of public accommodation, and Congress maintained that such discrimination threatens and substantially affects interstate commerce. ${ }^{74}$ When Title II was being considered by Congress, several senators charged that if the law were enacted, the Commerce Clause would be distorted beyond any recognizable limit; they argued that the federal government should not involve itself in the regulation of activities that are primarily intrastate in nature. Senator Monroney of Oklahoma, for example, found it "rather difficult to stretch the clause to cover an eating place simply because some of the meat moves from one state into another; or because the vegetables they serve come from Florida, or the oranges come from California." 75 The Court, however, was not troubled by

69. See id. at 113 .

70. See id at 114-15.

71. Id. at 119.

72. Id. at $127-28$.

73. The Lopez Coun clearly adopted Wickard's "in the aggregate" reasoning as pan and parcel of its "substantial effects" test. See United States v. Lopez, 115 S. Cl. 1624, 1634 (1995) ("The possession of a gun in a local school zone is in no sense an economic activity that might, through repeturion elsenhere. substantially affect any sort of interstate commerce.") (emphasis added).

74. Title Il provides: "All persons shall be enutled to the full and equal enjoyment of the goods. services, facilities, privileges, advantages, and accommodations of any place of public accommodauon. as defined in this section, without discrimination or segregation on the ground of race. color, religton, or national origin." 42 U.S.C. $\$ 2000 \mathrm{a}$ (1994).

75. GERALD GUNTHER, CONSTTTUTIONAL LAW 150 (12th ed. 1991) (quoung Heanngs Before the Senate Comm. on Commerce on S. 1732, 88th Cong., pts. I \& 2 (statement of Sen. Monroney)). Many) 
the intrastate character of the discriminatory conduct regulated by Title II and upheld the statute in Heart of Atlanta Motel v. United States ${ }^{76}$ and a companion case, Katzenbach v. McClung, ${ }^{77}$ reasoning that racial discrimination by business establishments, considered in the aggregate, substantially affects interstate commerce. Because these two decisions involve a civil rights law, unlike the Jones \& Laughlin Steel line of cases, they directly pertain to a determination of whether the VAWA Civil Rights Remedy has a sufficient interstate nexus.

Heart of Atlanta Motel held that a motel cannot refuse to lodge blacks on the basis of race and established that however local the motel's operations might seem, "discrimination by hotels and motels impedes interstate travel."" In upholding Title II of the 1964 Civil Rights Act, the Heart of Atlanta Motel Court set forth a highly deferential standard to determine whether legislation enacted under the Commerce Clause is constitutionally sound. The proper twopart test, the Court explained, is "(1) whether Congress had a rational basis for finding that racial discrimination by motels affected commerce, and (2) if it

congressmen and legal scholars protested at the time that Title II should be based on the Fourteenth Amendment, not the Commerce Clause. For example, Professor Gerald Gunther wrote:

The aim of the proposed anti-discrimination legislation, I take it, is quite unrelated to any concem with national commerce in any substantive sense.

It would, I think, pervert the meaning and purpose of the commerce clause to invoke it as the basis for this legislation. ... [I] would much prefer to see the Government channel its resources of ingenuity and advocacy into the development of a viable interpretation of the Fourteenth Amendment, the provision with a natural linkage to the race problem. That would seem to me a considerably less demeaning task than the construction of an artificial commerce facade....

Id. at 149 (quoting Letter from Gerald Gunther, Law Professor, Stanford University, to the Department of Justice (June 5, 1963)). Ultimately, Congress relied exclusively on the Commerce Clause, reasoning that to invoke the Fourteenth Amendment would create unnecessary risks. As Attomey General Robert F. Kennedy explained: "“[T]here is an injustice that needs to be remedied. We have to find the tools with which to remedy that injustice." Id. It is important to recognize, however, that Congress determined that reliance on the Fourteenth Amendment would invite constitutional challenges to Title II two years before Katzenbach v. Morgan, 384 U.S. 641 (1964), the most significant and expansive Section Five case of the modern era, had been decided. See infra text accompanying notes 152-54.

Echoing the debate over Title II, the argument has been made that the VAWA Civil Rights Remedy is fundamentally about securing women's equal protection under the laws, and is "unrelated to any concern with national commerce in any substantive sense." See, e.g., Victoria F. Nourse, Where Violence, Relationship, and Equality Meer: A Legislative History of the Violence Against Women's Civil Rights Remedy, 11 WIS. WOMEN's L.J. 1, 22 (1996) ("There is no question, of course, that Congress was aiming at discriminatory violence rather than the commerce itself."). Although this position has some merit, this Note grants both constitutional bases of the Remedy equal attention and respect because in relying on the Commerce Clause, Congress took the important step of acknowledging and underscoring the effects of gender-motivated violence on the public, commercial realm. With the VAWA Remedy in existence, gendermotivated violence can no longer be viewed as a private, hidden issue that state justice systems, see infra Section II.A, and even other civil rights laws, see infra text accompanying notes 176-79, have failed to address; the Remedy recharacterizes violence against women as a problem that negatively affects the most public of all spaces, the commercial marketplace, because women are essential to its operation. Therefore, the VAWA Remedy's Commerce Clause basis is not simply a constitutional hook on which to hang the legislation, but a significant statement about women's status and importance as commercial actors and citizens.
76. 379 U.S. 241 (1964).
77. 379 U.S. 294 (1964).
78. Heart of Atlanta Motel, 379 U.S. at 253. 
had such a basis, whether the means it selected to eliminate that evil are reasonable and appropriate."

The Court applied the "rational basis" test again in $\mathrm{McClung}$, which also involved a challenge to Title II of the 1964 Civil Rights Act. The defendant owned and operated a family restaurant, Ollie's Barbecue, and refused to serve black patrons in the dining area. After reviewing the legislative history of Title II, the Court again deferred to Congress's determination that the legislation was a rational means of protecting interstate commerce. ${ }^{80}$ As applied to Ollie's Barbecue, the Court concluded that Congress could reasonably have found that "established restaurants . . . sold less interstate goods because of the discrimination, that interstate travel was obstructed directly by $\mathrm{it}$, that business in general suffered and that many new businesses refrained from establishing there as a result." 81 As in Wickard and preceding cases, the Court in both Heart of Atlanta Motel and McClung was undeterred by the fact that the commercial establishments at issue in those cases served intrastate as well as interstate customers. The critical factor in both decisions was that the aggregate impact of the alleged racial discrimination substantially affected interstate commerce.

Commerce Clause jurisprudence before Lopez, from Jones \& Laughlin Steel to McClung, uniformly established that Congress is free to regulate intrastate activity that has a substantial effect on interstate commerce when considered in the aggregate. Since these cases were not overruled by Lopez, the decisions lend support to the position that an aciual jurisdictional element is not a prerequisite for the legitimate exercise of Congress's Commerce Clause power. Against the background of these cases, it is likely that Lopez does not mandate a jurisdictional element as a new requirement for Congress to follow. The VAWA Civil Rights Remedy, therefore, most likely will not be invalidated because of the absence of a jurisdictional tie. Because Congress demonstrated that gender-motivated violence has a substantial impact on interstate commerce when considered in the aggregate, ${ }^{82}$ there is a sufficient interstate nexus even by Lopez standards.

\section{The Regulation of Commercial Activity}

The second unresolved question raised by Lopez is whether Congress is permitted under the Commerce Clause to regulate noneconomic activity. If

79. Id. at $258-59$.

80. See McClung, 379 U.S. at 303-04. For other Commerce Clause cases using the "rational basis" test, see Preseault v. Interstate Commerce Comm 'n. 494 U.S. 1, 17 (1990): and Hodel v: Virgima Surfoce Mining \& Reclamation Ass'n, 452 U.S. 264, 276 (1981).

81. McClung, 379 U.S. at 300.

82. See supra Section I.A. As mentioned above. Lopez clearly sustanned Wickards "in the aggregate" test. See supra note 73. 
Lopez stands for the proposition that noneconomic intrastate activity-including activity that has a substantial effect on interstate commerce-cannot be regulated under the Commerce Clause, the VAWA Civil Rights Remedy will certainly be invalidated. The question of whether a regulated activity must be commercial in nature is more difficult to resolve than the necessity of a jurisdictional element because even the deferential (and still operative) Commerce Clause case law discussed above involves statutes that directly regulate commercial activity. Title II of the 1964 Civil Rights Act regulates business establishments, ${ }^{83}$ and the Jones \& Laughlin Steel line of cases deal with statutes that pertain to economic matters such as manufacturing operations, labor conditions, and wheat production and consumption. ${ }^{84}$ Therefore, although these cases are relevant after Lopez, they do not help answer the second troubling question raised by Lopez: Can a noneconomic intrastate activity that substantially affects interstate commerce, such as gendermotivated violence, be regulated under the Commerce Clause?

The Lopez opinion seemed in large part to be driven by the fact that the Gun-Free School Zones Act did not directly involve economic activity, and therefore the Act could not be upheld as a "regulation[] of activities that arise out of or are connected with a commercial transaction, which viewed in the aggregate, substantially affects interstate commerce." ${ }^{85}$ Apparently drawing a distinction between economic and noneconomic activity, ${ }^{86}$ the Lopez Court provoked the following inquiries: What constitutes economic activity? Do commercial activities only encompass the provision of goods and services? Or can Congress regulate activities that are so closely tied to market transactions that they substantially affect commerce? Without directly answering these questions, the Lopez Court offered multiple and contradictory signals regarding what it considered to be permissible regulation. ${ }^{87}$ In fact, the Lopez Court

83. Recall, however, that those who criticized Congress's invocation of the Commerce Clause in support of Title II would not have framed racial discrimination by places of public accommodation as an economic problem, but rather as a moral issue governed by Fourteenth Amendment concems with equality and citizenship. See supra note 75.

84. Although the Lopez Court characterized the production and consumption of homegrown wheat at issue in Wickard v. Filbum, 317 U.S. 111 (1942), as economic activity, see United States v. Lopez, 115 S. Ct. 1624, 1630 (1995), it is interesting to note, as Justice Breyer did in his Lopez dissent, that the Wickard Court itself did not focus on the commercial nature of the regulated activity. As Justice Brcyer explained, "the Wickard Court expressly held that Wickard's consumption of home-grown wheat, 'though it may not be regarded as commerce,' could nevertheless be regulated-'whatever its nature'-so long as 'it exerts a substantial economic effect on interstate commerce." Id. at 1663-64 (Breyer, J., dissenting) (quoting Wickard, 317 U.S. at 125). As mentioned above, the Lopez Court explicitly left Wickard in place. See supra note 60 and accompanying text.

85. Lopez, 115 S. Ct. at 1631 (emphasis added).

86. Note that the Lopez Court used the terms "commercial" and "economic" interchangeably. Compare, e.g., id. at 1633 ("Admittedly, a determination whether an intrastate activity is commercial or noncommercial may in some cases result in legal uncertainty."), with id. at 1634 ("The possession of a gun in a local school zone is in no sense an economic activity that might . . . substantially affect any sort of interstate commerce.").

87. Compare id. at 1631 (approving "regulations of activities that arise out of or are connected with a commercial transaction"), with id. at 1633 (explaining that Congress may "regulate numerous commercial 
openly admitted that "a determination whether an intrastate activity is commercial or noncommercial may in some cases result in legal uncertainty. ${ }^{\prime 88}$

The weight of the evidence, however, points to the conclusion that after Lopez, Congress is still free to regulate noncommercial activity that has a substantial effect on interstate commerce. The large majority of legal academics considering the question has adopted this moderate reading of Lopez, maintaining that Lopez did not draw a bright line between the regulation of economic and noneconomic activity. ${ }^{89}$ Furthermore, lower courts following Lopez have taken this less strict approach, approving the regulation of noncommercial activities that, in the words of the Lopez majority, "arise out of or are connected with a commercial transaction." Several federal appellate courts, for example, have upheld the federal arson statute against claims that it does not survive Lopez, reasoning that although the statute "does not regulate commercial or economic activity, it does regulate the damage or destruction of business property that satisfies the requisite interstate nexus." ${ }^{\text {"91 }}$ Like arson, gender-motivated violence, though only indirectly linked to commerce, has a substantial effect on economic activity. After all, when women are assaulted in their homes, or when their work choices are

activities that substantially affect interstate commerce").

88. Id. at 1633 .

89. See, e.g., Kathleen F. Brickey, Crime Control and the Commerce Clause Lufe After Lopez, 46 CASE W. RES. L. REV. 801 (1996) (maintaining that noncommercial, intrastate activity that adversely affects economic enterprise engaged in interstate commerce is still subject to Commerce Chuse junsdiction aftes Lopez); Robert F. Nagel, The Future of Federalism, 46 CASE W. RES. L. REV. 643. 648 (1996) (cnucizang Lopez Courts attempt to distinguish between commercial and noncommercial actuvitues as leading to "absurd" conclusions); Russell F. Pannier, Lopez and Federalism. 22 WM. MITCHEUL L REV 71. 96 (1996) (arguing that if Court had intended to distinguish between commercial and noncommeretal actuvity, ul would probably have explicitly "announce[d] such a dramatic change in the law"): Donald $H$. Zeigler. The New Activist Court, 45 AM. U. L. REV. 1367, 1397 (1996) ("[T]he commereial-noncommercial distinetion is reminiscent of the content-based or subject matter distinctions that the Cour used in an eariter era and abandoned as unworkable."); Maloney, supra note 29, at 1918 ("The best interpretnuon of Lope: is that the regulated activity must be tied in some way to economic actuvity."); John M. Scott. Notc. $18 \mathrm{~L}$. ARK LITTLE ROCK L.J. 513, 530 (1996) ("The Cour did not clarify whether it will allow Congress to regulate noncommercial activities to protect interstate commerce."). But see Anne C. Dailey. Federalism and Families, 143 U. PA. L. REV. 1787, 1817 (1995) ("[T]he Coun removed noneconomic local activity-whatever its effect on interstate commerce-from the scope of federal regulatory power.").

90. $115 \mathrm{~S}$. Ct. at 1631. See, e.g., United States v. Wilson. 73 F.3d 675, 685 (7th Cir 1995) ("(W)e find no support for reading Lopez as permitting oniy regulation of economic actuvitues exclusive of regulations that reach or affect economic activitues. The Court's language is clear that the substantual effects test is not so limited....").

91. United States v. DiSanto, 86 F.3d 1238, 1245 (1st Cir. 1996) (citatuon omitted); see also Linited States v. Sherlin, 67 F.3d 1208, 1213-14 (6th Cir. 1995) (rejecung Lope: challenge to federal arson statute) Although the federal arson statute has been upheld by lower courts after Lopes despite the fact that it regulates noncommercial activity, it is important to note that the statute does contan a junsdictional element that ensures an interstate nexus. The statute provides: "Whoever maliciously damages or destroys ... any ... property used in interstate or foreign commerce or in any acuvily affecting interstate or foreign commerce shall be imprisoned for not less than five years and not more than twenty years. fined under this title, or both ... ." 18 U.S.C. \$ 814(i) (1994). 
constrained by fear for their own safety, there is a tangible effect on the operations of the national economy. ${ }^{92}$

Not only is it evident that the VAWA Remedy is analogous to the federal arson statute, which has been upheld by lower courts after Lopez, but also it can be argued that the economic effect of gender-motivated violence is more direct, immediate, and substantial ${ }^{93}$ than the economic impact of permitting guns in school zones. The VAWA Remedy, unlike the Gun-Free School Zones Act, would not require that the Court "pile inference upon inference" order to find a substantial link to interstate commerce. In Lopez, the Government maintained in its brief that "the presence of guns in schools poses a substantial threat to the educational process by threatening the learning environment. A handicapped educational process, in turn, will result in a less productive citizenry." 95 This reasoning entails several levels of conjecture and hypothesis: The possession of firearms in schools may cripple the educational process; a "handicapped educational process" may result in a "less productive citizenry"; and finally, a "less productive citizenry" may have "an adverse effect on the Nation's economic well-being." "96 Unlike the Gun-Free School Zones Act, which regulates activity that might lead to violent crime, the VAWA Civil Rights Remedy targets violent crime, gender-motivated violence, directly. Moreover, gender-motivated violence has a necessary and substantial, not a tenuous or speculative, connection to interstate commerce. Gendermotivated violence directly prevents women from participating in the workforce; it has an immediate and measurable effect on national productivity. ${ }^{97}$ Even the Brzonkala court, while striking down the Civil Rights Remedy on Commerce Clause grounds, conceded that "the case at hand possibly involves one less step than the postulated effects in Lopez."

\section{The Gun-Free School Zones Act Distinguished}

Whether or not the VAWA Civil Rights Remedy survives Lopez depends in large part on how the jurisdictional element requirement is construed, and on how the commercial/noncommercial distinction plays itself out in future cases. Beyond these two central questions, however, there are several additional ways of distinguishing the VAWA Remedy from the Gun-Free School Zones Act struck down in Lopez.

92. See supra Section I.A.

93. The Lopez Court describes the Gun-Free School Zones Act as too tenuously related to interstate commerce, see $115 \mathrm{~S}$. Ct. at 1632-33, but never defines or elaborates on its "substantial effects" test.

94. Id. at 1634.

95. Id. at 1632 .

96. Id.

97. See supra Section I.A.

98. Brzonkala v. Virginia Polytechnic \& State Univ., 935 F. Supp. 772, 790 (W.D. Va. 1996). 
First, the VAWA Civil Rights Remedy is distinguishable from the GunFree School Zones Act because it does not invade areas of law traditionally reserved for state regulation. The Lopez Court expressed concern that if the Gun-Free School Zones Act were upheld, Congress's Commerce Clause power would be virtually unlimited, and the delicate balance between state and federal jurisdiction would be disturbed. ${ }^{99}$ The Court specifically identified "education," "family law (including marriage, divorce, and child custody)," and "criminal law enforcement" as areas "where States historically have been sovereign." under the Commerce Clause, it seems likely that this restraint will manifest itself in terms of closer scrutiny of legislation involving these three targeted areas. The VAWA Civil Rights Remedy, however, leaves all three traditional areas of state sovereignty untouched. ${ }^{101}$ The Remedy obviously does not involve education and cannot be considered a "family law" for two important reasons. First, its scope is not restricted to domestic relations; it regulates gender-motivated violence regardless of whether the perpetrator is related to the victim. Second, the Remedy expressly excludes "any State law claim seeking the establishment of a divorce, alimony, equitable distribution of marital property, or child custody decree." 102 Therefore, the VAWA Remedy excepts the precise areas the Lopez Court defined as family law, namely "marriage, divorce, and child custody." 103

Perhaps even more importantly, the VAWA Remedy is a civil rights law, not a criminal statute. ${ }^{104}$ This fact is significant because the Lopez Court repeatedly and emphatically underscored the fact that '.' [s]tates possess primary authority for defining and enforcing the criminal law." 10 In contrast with the Gun-Free School Zones Act, the VAWA Civil Rights Remedy does not interfere with states' power to govern themselves or to prescribe their own criminal laws. Underscoring the inadequacy of remedies available at the state level, the Remedy merely offers an alternative way for victims of gendermotivated violence to be compensated for their injuries. As the Connecticut

99. See Lopez, 115 S. Ct. at 1632 ("[I]f we were to accept the Government"s arguments, we are hardpressed to posit any activity by an individual that Congress is without power to regulate ")

100. Id.

101. See Maloney, supra note 29 , at 1927-28.

102. 42 U.S.C. \& 13981 (e)(4) (1994).

103. In opposing the Civil Rights Remedy during the VAWA congresstonal heanngs, the Conference of Chief Justices took the opposite view, maintaining that the Remedy "would Impair the ability of state courts to manage criminal and family law matters traditionally entrusted to the states." Crumes of Violence. supra note 1, at 83 (statement of Conference of Chief Justices) (emphasis added).

104. Note that many federal civil rights statutes in addition to Title II of the 1964 Cival Rughts Act have been enacted and upheld under the Commerce Clause. See, e.g. EEOC v. IVyomıng, 460 U.S. 226. 243 (1983) (Age Discrimination in Employment Aat of 1967): Fitzpatnck v. Bitzer. 427 U.S. 45 , 48 (1976) (1972 Amendments to Title VII of 1964 Civil Rights Act): Abbott v. Bragdon. 912 F. Supp 580. 592-94 (D. Me. 1995) (Americans with Disabilities Act of 1990)

105. Lopez, 115 S. Ct. at 1631 n.3 (quoting Brecht v. Abrhamson. 507 U.S. 619.635 (1993)) (cituron omitted); see also id. at 1634 (explaining that Gun-Free School Zones Act represents federal encroactunent on "the general police power of the sort retained by the States"). 
district court reasoned in Doe, the VAWA Remedy "does nothing to infringe on a state's authority to arrest and prosecute an alleged batterer on applicable criminal charges.... [N]othing in VAWA precludes a victim of domestic violence from bringing a tort action in state court ..."106 Moreover, while providing an alternative forum for victims of gender-motivated violence, the Remedy exposes flaws in the state system's handling of such violence. Victoria Nourse, one of the drafters of the Remedy, describes the Remedy as a constructive learning device, a lesson for both state justice systems and the public at large:

VAWA's remedy is ... a classic civil rights remedy: it does not directly punish the State that has failed to prosecute acquaintance rape cases or to arrest spouse abusers. Instead, it seeks to force courts to address the reasons "why" those practices exist by exposing the very same prejudices in the conduct subject to suit. ${ }^{107}$

A "classic" civil rights law that educates and compensates in response to failures in the state system is easily distinguished from the Gun-Free School Zones Act, which coopted states' control over their own criminal laws. ${ }^{108}$

There is a second, equally significant, way to distinguish the VAWA Civil Rights Remedy from the Gun-Free School Zones Act. The Lopez majority noted its disapproval of the absence of congressional findings to support the Government's claim that the possession of guns in school zones has a substantial effect on interstate commerce. Chief Justice Rehnquist explained:

Congress normally is not required to make formal findings as to the substantial burdens that an activity has on interstate commerce. But to the extent that congressional findings would enable us to evaluate the legislative judgment that the activity in question substantially affected interstate commerce, even though no such substantial effect was visible to the naked eye, they are lacking here. ${ }^{109}$

106. 929 F. Supp. 608,616 (D. Conn. 1996). This passage highlights the contrast between the VAWA Remedy and the Gun-Free School Zones Act which, as Justice Kennedy argued in his concurrence. "foreclose[d] the States from experimenting and exercising their own judgment in an area to which States lay claim by right of history and expertise ...." Lopez, $115 \mathrm{~S}$. Ct. at 1641 (Kennedy, J., concurring).

107. Nourse, supra note 15, at 18-19 (emphasis added) (footnote omitted). Other academic commentators agree that the Civil Rights Remedy is an effective educational tool. See, e.g., Goldfarb, supra note 16, at 399 ("[T] instrument in the continuing effort to advance our understanding of what causes violence against women and what we can do to stop it.").

108. However, the mere fact that a statute is criminal does not seem fatal even after Lopez. See, e.g., Doe, 929 F. Supp. at 615 ("Notwithstanding Lopez's conclusion that 'states possess primary authority for defining and enforcing criminal law, dozens of courts throughout the country, post-Lopez, have upheld a variety of federal criminal . . . enactments as constitutional under the Commerce Clause . . . .") (citations omitted). See generally Weaver, supra note 59 (describing evolution of federal criminal law and predicting that Lopez would not jeopardize existing federal criminal statutes).

109. $115 \mathrm{~S}$. Ct. at $1631-32$ (citations omitted). 
As discussed in the previous Section, the VAWA Remedy, in contrast with the Gun-Free School Zones Act, has a voluminous legislative history substantiating the link between gender-motivated violence and interstate commerce. ${ }^{110}$ This record shows that Congress seriously deliberated on the factual and constitutional issues that surrounded the Remedy's enactment; unlike the GunFree School Zones Act, Congress did not merely assert its Commerce Clause power without justification.

The question then becomes how much weight cours should accord these congressional findings when they do exist. The Fifth Circuit's invalidation of the Gun-Free School Zones Act in Lopez focused considerably on the absence of legislative findings and declared that courts "almost always" defer to congressional findings: "Where Congress has made findings, formal or informal, that regulated activity substantially affects interstate commerce, the courts must defer 'if there is any rational basis for' the finding. . . . Practically speaking, such findings almost always end the matter."'I' Several decisions in the wake of Lopez have approached congressional findings with a similar level of deference, following the Fifth Circuit's rational basis standard. For example, in distinguishing FACE from the Gun-Free School Zones Act, the Seventh Circuit maintained that although legislative findings are not technically required, "[i]t is easy enough to imagine congressional findings that, if found rational, could have made Lopez a very different case. . . The point is that congressional findings matter."112 Academic commentators have posited that Lopez sent the message that the "'federalization of state crime can continue without constitutional limit so long as there are legislative findings'.... The Commerce Clause is not a real obstacle but an obligatory hoop."

Although some lower courts and legal academics considering Congress's Commerce Clause power after Lopez have adhered to the Fifth Circuit's deferential standard, it appears that Chief Justice Rehnquist's opinion for the Lopez majority set the stage for an approach that places considerably less weight on legislative findings. Recall that the Lope: Cour described congressional findings as a supplementary aid that "would enable [the Court] to evaluate the legislative judgment."1/4 In marked contrast to the Fifth Circuit opinion, the Lopez Court treated legislative findings as an additional

110. See supra Section I.A.

111. United States v. Lopez, 2 F.3d 1342, 1363 (5th Cir. 1993) (ctitions omithed). aff'd. 115 S. Cl. 1624 (1995).

112. United States v. Wilson, 73 F.3d 675. 684 (7th Cir. 1995). Simularly. in upholding a cocaune distribution conspiracy statute against a Lopez challenge. the Second Circuit relied in large pan on the presence of specific findings that local narcotics activity has a substantial effect on interstate commerce. See United States v. Genao, 79 F.3d 1333. 1337 (2d Cir. 1996).

113. Barry C. Toone \& Bradley J. Wiskirchen. Note, Great Expectattons: The Illuston of Federaltsm Afrer United States v. Lopez, 22 J. LEGIS. 241. 263-64 (1996) (quoting Thomus M. Mengler. The Sad Refrain of Tough on Crime: Some Thoughts on Saving the Federal Judiciang from the Federalizanton of State Crime, 43 KAN. L. REV. 503, 512 (1995)).

114. $115 \mathrm{~S}$. Ct. at 1632. 
consideration, "one source of potential support for the proposition that the statute had a rational connection to interstate commerce." Nevertheless, although Lopez suggests that legislative findings are not profoundly influential, these findings are likely to assume greater importance in a close case, such as the VAWA Civil Rights Remedy, where the activity's effect on interstate commerce is not intuitively obvious or immediately apparent. In Lopez, Chief Justice Rehnquist emphasized the significance of legislative findings in view of the fact that "no such substantial effect [on commerce] was visible to the naked eye." 116 In his Lopez dissent, Justice Breyer explained that congressional findings offer "the benefit of some extra leeway," which "in principle, might change the result in a close case."117 Therefore, although the presence of legislative findings accompanying the VAWA Remedy might not be a dispositive factor, and although courts will exercise independent judgment despite the existence of substantial findings, to dissenting Justice Souter, legislative findings undoubtedly "shrink[] the risk that judicial research will miss material scattered across the public domain or buried under pounds of legislative record." 118

Finally, the VAWA Remedy can be distinguished from the Gun-Free School Zones Act on the ground that it is supported by an entirely separate constitutional basis: Congress's power under Section Five of the Fourteenth Amendment to remedy equal protection violations at the state level. The fact that the VAWA Civil Rights Remedy is partially rooted in Congress's finding that state systems nationwide have often failed victims of gender-motivated violence bolsters the Commerce Clause claim that gender-motivated violence is not a local issue suitable for state jurisdiction exclusively. The VAWA Civil Rights Remedy, unlike the Gun-Free School Zones Act, is backed by a federal interest apart from interstate commerce: a federal interest in ensuring that victims of gender-motivated violence are afforded equal protection of the laws. The equal protection issues at stake, described in the next Part, inform and complement the Commerce Clause analysis because these unmistakably federal

115. Philip P. Frickey, The Fool on the Hill: Congressional Findings, Constitutional Adjudication, and United States v. Lopez, 46 CASE W. RES. L. REV. 695, 707 (1996). Frickey also indicates that the Fifth Circuit's approach finds no support in New Deal or post-New Deal Commerce Clause cases such as Jones \& Laughlin Steel, Wickard, and Katzenbach v. McClung. See id. at 711-13. Other legal academics have agreed that the Lopez Court did not place significant emphasis on the presence or absence of congressional findings. See, e.g., Barry Friedman, Legislative Findings and Judicial Signals: A Positive Political Reading of United States v. Lopez, 46 CASE W. RES. L. REv. 757, 772 (1996) ("Lopez was a decision squarely on the merits. In other words, regardless of what findings Congress had adopted, the Lopez Court would not have upheld the regulation of guns near schools as an exercise of the commerce power."). The Connecticut court in Doe v. Doe also followed this less deferential approach to legislative findings: "While the Court's inquiry is an independent one, it will consider congressional findings, including congressional committee findings." 929 F. Supp. 608, 612 (D. Conn. 1996).

116. $115 \mathrm{~S}$. Ct. at 1632 (emphasis added).

117. Id. at 1658 (Breyer, J., dissenting) (emphasis omitted); see also id. at 1656 (Souter, J., dissenting) (maintaining that legislative findings are particularly helpful in "difficult" or "close" cases).

118. Id. at 1657 (Souter, J., dissenting); see also Maloney, supra note 29, at 1931-32. 
issues add weight to the assertion that gender-motivated violence is a problem that crosses state lines and affects the health and well-being of the entire nation. In essence, Congress's invocation of both the Commerce Clause and the Equal Protection Clause to remedy the problem of gender-motivated violence sends the same message: Women have the right to full and equal citizenship-both in terms of participation in the national economy and in terms of protection by the criminal justice system.

\section{THE VAWA CiVIL Rights REMEdy as a VAlid ENForCENENT OF EQUAL PROTECTION}

In addition to the Commerce Clause, Congress relied on Section Five of the Fourteenth Amendment as a constitutional basis for the VAWA Civil Rights Remedy. ${ }^{119}$ Section Five provides that, "Congress shall have power to enforce, by appropriate legislation, the provisions" of the Fourteenth Amendment. ${ }^{120}$ In this instance, Congress aimed to enforce Section One of the Fourteenth Amendment, which states that, "[n]o State shall . . . deny to any person within its jurisdiction the equal protection of the laws." ${ }^{212}$ Congress invoked Section Five because it aimed to provide victims of gender-motivated violence with equal protection of the laws where state systems had failed. The potential assaults on Congress's authority to enact the Remedy under Section Five are considerably less threatening than the post-Lopez Commerce Clause challenges discussed above. Attacks on the Section Five basis of the Civil Rights Remedy generally maintain that the Remedy's proscription of "purely private conduct" violates the state action limit of the Fourteenth Amendment. This Part argues that the VAWA Remedy falls within the judicially circumscribed limits of Section Five because Section Five is not limited by the same state action requirement as Section One. In reaching that conclusion, this Part first describes the widespread gender inequality that pervades the state criminal justice system, drawing on congressional hearings that indicate that gender-motivated violence presents equal protection problems at the state level that demand a federal remedy. The following Section then analyzes the extent and limits of Congress's power under Section Five and argues that the VAWA Civil Rights Remedy fits comfortably within those limits. This Part further maintains that the Civil Rights Remedy is "appropriate legislation" within the meaning of Section Five because it is specifically tailored to combat the critical problem of violence against women, and is therefore an effective means of enforcing the Equal Protection Clause.

119. See 42 U.S.C. \$ 13981(a) (1994). Note that Doe v: Doe upheld the Cival Rughis Remedy on Commerce Clause grounds only. The cour did not reach the question of whether the Remedy could be sustained on the basis of Section Five as well. See 929 F. Supp. at 612 n.S.

120. U.S. CONST. amend. XIV, § 5.

121. Id. § 1 . 


\section{A. Inequality in the State System}

Congress enacted the VAWA Civil Rights Remedy based on an extensive legislative record that documented the many ways in which state courts do not afford female crime victims equal protection of the laws as guaranteed by Section One of the Fourteenth Amendment. Gender bias and discrimination within the state system frequently deprive women of the protection to which they are entitled. ${ }^{122}$ As Senator Biden described the problem on introducing the VAWA Remedy to Congress: "[I]t is still easier to convict a car thief than a rapist, and, authorities are more likely to arrest a man for parking tickets than for beating his wife ...."123 This Section summarizes the statistics, reports, and testimony gathered at the VAWA congressional hearings and concludes that because of the states' failure to provide equal protection to victims of gender-motivated violence, Congress had legitimate cause for creating the VAWA Civil Rights Remedy.

Obstacles to equal treatment for female victims of violence within the state system exist at both legal and administrative levels. On a legal level, state statute books are rife with formal bars to equality. For example, some states still retain a marital exemption to laws prohibiting rape; ${ }^{124}$ several states also heighten the legal standards for proving sexual assault against cohabitants and dating companions. ${ }^{125}$ Another legal barrier to equality is the interspousal immunity doctrine, which in some states still prevents battered women from suing their husbands to recover damages for either medical expenses or pain and suffering. ${ }^{126}$ Strict statutes of limitations, yet another legal obstacle in

122. See generally Hallock, supra note 16, at 595-99 (describing formal and informal barriers to gender equality in state criminal justice systems); Developments in the Law-Legal Responses to Domestic Violence, 106 HARV. L. REV. 1498, 1530-43 (1993) [hereinafter Developments] (indicating insufficiency of recent state reforms in civil and criminal laws, arrest and prosecution policies, and sentencing and treatment programs).

123. 137 CONG. REC. S597-98 (daily ed. Jan. 14, 1991) (statement of Sen. Biden).

124. See S. REP. No. 102-197, at 45 n.50 (1991). Although most states no longer have marital rape exemptions, four states-Kentucky, Louisiana, Oklahoma, and South Carolina-have retained them. See Ky. Rev. Stat. ANN. § 510.035 (Michie Supp. 1994); LA. REv. STAT. ANN. \& 14:43 (West Supp. 1996) OKLA. STAT. ANN. tit. 21, § 1111 (West Supp. 1997); S.C. CODE ANN. § 16-3-658 (Law Co-op. Supp. 1997). A substantial number of states that have abolished the marital rape exemption, however, still treat marital rape differently from nonmarital rape. These states either impose lesser penalties on perpetrators of marital rape, compare, e.g., W. VA. CODE § 6I-8B-3 (1992 \& Supp. 1996) (establishing that sexual assault in first degree is punishable by imprisonment of not less than 15 nor more than 35 years), with id. § 61-8B-6 (establishing that sexual assault of spouse, while still felony, is punishable by imprisonment of not less than two nor more than ten years), or create higher legal standards for proving marital rape than for proving nonmarital rape, compare, e.g., MisS. CODE ANN. § 97-3-95(1)(a) (1972 \& Supp. 1996) (defining sexual battery as sexual penetration of another person without his or her consent), with id. \$ 97-399 (providing that spouse of alleged victim may be found guilty of sexual battery only if spouse engaged in forcible sexual penetration without consent of alleged victim). For an overview of the history of the marital rape exemption and each state's current approach to spousal rape, see Emily R. Brown, Note, Changing the Marital Rape Exemption: I Am Chattel (?!); Hear Me Roar, 18 AM. J. TRIAL ADvoc. 657 (1995).

125. See, e.g., DEL. CODE ANN. tit. 11, §§ 774-75 (1995).

126. See LeONARD KARP \& ChERYL L. KARP, DOMESTIC TORTS: FAMILY VIOLENCE, CONFlict AND 
some states, pose particular problems for young victims of sexual assault, who permanently lose their opportunity to pursue a civil remedy if they fail to bring suit within a few years of the attack. ${ }^{127}$

In addition to marital rape exemptions, interspousal tor immunities, and statutes of limitations, which restrict the availability of prosecution for gendermotivated crimes, there are also discriminatory laws that obstruct justice at the trial level. For example, state rape shield laws do not apply in civil cases, so that "women bringing tort actions for sexual assault are routinely subjected to intrusive questions about consensual sexual activity unrelated to the attack." 128 Furthermore, most jurisdictions still adhere to the common law "fresh complaint rule," which creates a rebuttable presumption against the credibility of rape complaints that are not filed immediately after the alleged assault. ${ }^{129}$ Although study after study shows that delays in reporting are to be expected because of the trauma caused by sexual assault, ${ }^{130}$ the fresh complaint rule is still used to identify false repors. Along similar lines, pattem jury instructions used in state courts nationwide require that juries be reminded of the ever-present possibility of false reporting. ${ }^{131}$ Even the Model Penal Code suggests that juries in sexual assault cases "be instructed to evaluate the testimony of a victim or complaining witness with special care in view of the emotional involvement of the witness and the difficulty of determining the truth [of the allegation]."132

These legal barriers to equality are compounded by discriminatory administrative practices, which undermine whatever protection is provided by the letter of state law. Congressional hearings on the VAWA Remedy showed that gender bias contaminates every level of the state system, and that insensitive and unresponsive treatment by police, prosecutors, and judges often results in low reporting and conviction rates. Police, responsible for the initial screening of cases, are notorious for not responding to situations involving violence against women, particularly domestic violence. The Fund for the Feminist Majority reported at the VAWA legislative hearings that " $23 \%$ of

SEXUAL ABUSE $\$ 1.16$ (1995) (cataloging status of interspousal ummunty doanne in each state)

127. In New York, for example, the statute of limitations for intentional torts such as assauth and battery is one year. See N.Y. C.P.L.R. 215(3) (Consol. 1990). See generally NOW LEGAL DEFENSE AND EdUC. FUND, LEGAL RESOURCE KIT: INCEST AND CHLD SEXUAL ABUSE (1996) (desenbing how stalutes of limitations impose unique burdens on minors and catalogung state stalutes of limitalıons for ervil uncest and child sexual abuse cases).

128. Crimes of Volence, supra note 1, at 9 (statement of Sally Goldfarb. Semor Staff Altonny. NOW Legal Defense and Education Fund). Consider, for example, one case in lowa where the "unal judge authorized the defense lawyer to ask the vatim . . . about her 'ullegumate' relationshp to her boytand and use of birth control, and about her reputation of having 'wild partes' wath a lot of men 'coming and going." S. REP. 102-197, at 46 (1991) (quoting unpublished opinion in Sindelar v W'etner. Civ No 89. 1177 (Iowa)).

129. See Mornson Torrey, When Will We Be Believed? Rape M/vils and the Idea of a Fair Tral in Rape Prosecutions, 24 U.C. DAVIS L. REV, 1013. 1041-43 (1991)

130. See id. at 1016 n.10.

131. See id. at 1046.

132. MOdel PENAL CODE $\S 213.6(5)$ (1980). 
women who decline from reporting their being raped to the police do so because they thought the police would be inefficient, ineffective, or insensitive." 133 An internal investigation of the Oakland, California Police Department found that ninety percent of the sexual assault reports that were determined to be unfounded in 1989 and 1990 should have been further investigated. ${ }^{134}$ The Oakland investigation further discovered that one out of every four women who reported a rape or attempted rape to the Oakland Police during those years was ignored. ${ }^{135}$

Equally problematic is the well-documented fact that prosecutors often fail to enforce vigorously laws prohibiting gender-motivated violence. As one commentator described: "Faced with limited time, personnel, and resources . . . prosecutors often give domestic violence cases low priority and sometimes even try to persuade battered women not to prosecute."136 At the congressional hearings on the Civil Rights Remedy, it was readily apparent that prosecutors across the country either refuse to charge or significantly undercharge alleged perpetrators of sex crimes:

\begin{abstract}
Witnesses told of counties in which no acquaintance rape prosecutions had been brought .... They quoted from Justice Department studies showing that most domestic violence cases caused injuries as serious as most felonies and, yet, experience demonstrated that most domestic violence crimes were charged as misdemeanors. They testified about threats to witnesses routinely prosecuted in drug cases but ignored in domestic abuse cases. ${ }^{137}$
\end{abstract}

In fact, a civil rights case that will be decided by the Supreme Court this Term offers a paradigmatic illustration of state prosecutors' unwillingness to bring charges in cases of alleged sexual assault. The case, United States $v$. Lanier, ${ }^{138}$ involves a Tennessee Chancery Court judge ultimately convicted in federal court of sexually assaulting five women on five separate occasions in his chambers, at times dressed in his judicial robes. One of Judge Lanier's victims was a litigant with a child custody matter before his court; the other four victims were court employees or women who worked with the judge in

133. Crimes of Violence, supra note 1, at 118 (statement of the Fund for the Feminist Majority, Gender Balance in the Police Force: Responding to Violence Against Women) (citing CATHERINE WoLF, U.S. DEP'T OF JUSTICE, FEMALE VICTIMS OF VIOLENT CRIME (1991)).

134. See id. (citing Police Were Wrong in Rapes, Chief Says, L.A. TIMES, Feb. 4, 1991).

135. See id. There is a considerable amount of anecdotal and statistical evidence of police failure to protect female victims of violence. See, e.g., Thurman v. City of Torrington, 595 F. Supp. 1521, 1525-26 (D. Conn. 1984) (stating that husband stabbed wife repeatedly, then kicked and threatened her while police were present); DEL MARTIN, BATTERED WIVES 90-99 (1976); DEBORAH L. RHODE, JUSTICE AND GENDER 239 (1989).

136. Developments, supra note 122 , at 1540 .

137. Nourse, supra note 15 , at 17-18 (footnotes omitted).

138. 73 F.3d 1380 (6th Cir.) (en banc) (holding that 18 U.S.C. $\S 242$ (1994), which proscribes constitutional violations committed under color of state law, does not encompass sexual assault by state judge acting in official capacity), cert. granted, 116 S. Ct. 2522 (1996). 
his official capacity. But because Judge Lanier's brother was the county prosecutor, and because his family had "occupied positions of power and political authority in Dyersburg, Dyer County, Tennessee, for several generations," 139 it is doubtful that his criminal conduct would ever have been prosecuted in state court. ${ }^{140}$ In the end, Judge Lanier's sexual assaults were only exposed and federally prosecuted because of an unrelated federal investigation into suspected political corruption involving Judge Lanier and his brother. ${ }^{141}$ The facts of the Lanier case vividly support the claim that because of local affiliations and prejudices, state prosecutors often fail to enforce criminal protections against gender-based violence.

Gender bias exists among state court judges as well. For example, the Washington State Task Force on Gender and Justice in the Courts reported that nearly one "quarter of the [state judges] believed that rape victims 'sometimes' or 'frequently' precipitate their sexual assaults because of what they wear and/or actions preceding the incidents." 42 One state court judge told a domestic violence victim seeking protection in his court, "'Let's kiss and make up and get out of my court." 143 The New York State Task Force found that some judges "shunt victims back and forth between police and family court until they give up seeking protection."144

\section{B. The Reach of Congress's Enforcement Power}

In the face of this evidence demonstrating that state justice systems discriminate against female victims of violence at every level, some remain convinced that state courts afford victims of gender-motivated violence equal protection of the laws. For example, one law professor has argued that because violence against women "is already adequately covered by state law," the VAWA Remedy is a "wasteful duplication of resources." is Most critics, however, do not contest the extensive findings of widespread bias in the state court system, ${ }^{146}$ but instead argue that as an antidote to this inequity, the VAWA Civil Rights Remedy exceeds Congress's power under Section Five

139. Id. at 1394 (Wellford, J., concurnng in part and dissenung in part).

140. See DARCY O'BRIEN, THE POWER TO HURT (1996) (documentung enture history of investugatuon and prosecution of Lanier case).

141. See id.

142. S. REP. NO. 102-197, at 47 n.63 (1991).

143. Quoted in Women and Volence: Hearing on Legislatson to Reduce the Growing Prablem of Violent Crime Against Women Before the Senate Comm. on the Judician (Part 1). 10ist Cong 65 (1990)

144. Id. (citing Lynn Hecht Schafran, Documenting Gender Btas in the Courts. The Task Force Approach, 70 JUDICATURE 280, 283-84 (1987)). (1995)

145. Sanford H. Kadish, Comment, The Folly of Overjederalizalion. 46 Hastivas LJ 1247, 1249

146. See, e.g., Brzonkala v. Virginia Polytechnic \& State Unıv., 935 F. Supp. 779, 800 (W.D Va. 1996) ("Some possibility exists that at least part of the states" differental treatment of gender-based violent crimes against women is due to gender discrimination. and so correcung the differentsal treatment ansing out of gender discrimination is a legitimate Fourteenth Amendment concem."). 
to enforce the Equal Protection Clause of the Fourteenth Amendment. ${ }^{147}$ This Section defends the Civil Rights Remedy's Section Five basis, maintaining that the Remedy does not exceed the established limits of Congress's authority under Section Five.

Although case law describing Congress's power to enforce the terms of the Civil War Amendments is minimal, it uniformly demonstrates that legislative enforcement power can reach beyond the limits of the self-executing provisions of the Thirteenth, Fourteenth, and Fifteenth Amendments. Jurisprudence concerning congressional enforcement power began its serious development in the 1960s, following a proliferation of congressional legislation protecting civil rights. In South Carolina v. Katzenbach, ${ }^{148}$ the Court upheld a provision of the Voting Rights Act of 1965 that suspended literacy tests, despite the fact that a unanimous Court had rejected a facial challenge to literacy tests seven years earlier. ${ }^{149}$ In a decision extraordinarily deferential to Congress's enforcement power, the Court granted Congress the freedom to enforce the Fifteenth Amendment's guarantee of a racially unconditioned right to vote as it saw fit; Congress would not be constrained by the Court's own notion of what constituted a violation of the Fifteenth Amendment. The Court broadly stated that, "Congress has full remedial powers to effectuate the constitutional prohibition against racial discrimination in voting" as long as Congress "attack[s] evils ... comprehended by the Fifteenth Amendment."150 The Katzenbach Court further announced that it would review congressional exercise of its enforcement power according to a generous "rational basis" standard. ${ }^{151}$ In essence, the Court made clear that Congress in its enforcement capacity could legislate against conduct that would not in and of itself qualify as a violation of the self-executing provision of the Fifteenth Amendment. ${ }^{152}$

147. See, e.g., id. at 793-801.

148. 383 U.S. 301 (1966).

149. See Lassiter v. Northampton County Bd. of Elections, 360 U.S. 45 (1959).

150. Katzenbach, 383 U.S. at 326.

151. See id. at 324 . Other decisions reviewing congressional enforcement legislation have invoked the Katzenbach "rational basis" standard. See, e.g., City of Rome v. United States, 446 U.S. 156, 177 (1980) (Fifteenth Amendment); Jones v. Alfred H. Mayer Co., 392 U.S. 409, 440 (1968) (Thirteenth Amendment). Note that this deferential standard is akin to the one used in Commerce Clause cases such as Heart of Atlanta Motel v. United States, 379 U.S. 241 (1964); and Katzenbach v. McClung, 379 U.S. 294 (1964). See supra notes 79-80 and accompanying text. Also note that in determining whether a rational basis existed for Congress's enactment, the McClung Coun was persuaded by the fact that there was a "voluminous legislative history" supporting the enactment. See 379 U.S. at 309. As described in Section II.A, the VAWA Civil Rights Remedy also has a "voluminous legislative history" demonstrating that Congress had a rational basis supporting this effort to enforce equal protection.

152. City of Rome offers a more recent statement of this holding. See 446 U.S. at 177 ("It is clear . . that under $\S 2$ of the Fifteenth Amendment Congress may prohibit practices that in and of themselves do not violate $\S 1$ of the Amendment, so long as the prohibitions attacking racial discrimination in voting are 'appropriate' ...."). 
With respect to congressional legislation enforcing the Fourteenth Amendment, the leading case is Katzenbach v. Morgan, ${ }^{153}$ which upheld a provision of the Voting Rights Act of 1965 that nullified New York's English literacy requirement. Following the pattern and logic of South Carolina $v$. Katzenbach, the Court approved the statute despite its own determination in a previous case that the New York literacy requirement did not violate the Equal Protection Clause itself. Invoking the deferential Katzenbach standard of review, the Morgan Court was satisfied with the legislation at issue simply because it was "able to perceive a basis upon which the Congress might resolve the conflict as it did." 154 According to the Morgan Cour, "[c]orrectly viewed, $\S 5$ is a positive grant of legislative power authorizing Congress to exercise its discretion in determining whether and what legislation is needed to secure the guarantees of the Fourteenth Amendment."1ss

Katzenbach and Morgan stand for the proposition that the range of conduct that Congress is permitted to legislate against pursuant to its enforcement power surpasses the scope of activity that would constitute a violation of the self-executing provisions of the Fourteenth and Fifteenth Amendments. As constitutional law scholar Burt Neuborne explained at the VAWA congressional hearings: "[T]he modern Supreme Court has explicitly ruled that Congress' power under Section 5 exceeds the self-executing reach of Section 1."156 Recently, in upholding the Religious Freedom Restoration Act of 1993

153. 384 U.S. 641 (1966).

154. Id. at 653 .

155. Id. at 651 (emphasis added). A plurality of the Court affirmed the pnnciples of Alorgan in the affirmative action context in Ciny of Richmond v. J.A. Croson Co. 488 U.S. 469 (1989) (plurality opinion). stating, "Congress ... has a specific constitutional mandate to enforce the dictates of the Fourteenth Amendment. The power to 'enforee' may at times also include the power to define situations which Congress determines threaten principles of equality and to adopt prophylactic nules to deal with those situations." Id. at 490; see also Metro Broad., Inc. v. FCC, 497 U.S. 547. 605-06 (1990) (O'Connor. J . dissenting) ("Congress has considerable latitude, presenting spocial concems for judicial review; when "l exercises its "unique remedial powers . . . under $\$ 5$ of the Fourteenth Amendment." ${ }^{\prime \prime}$ ) (citation omitted) (ellipsis in original). The Cour's opinion in Adarand Constructors. Inc. v. Pena. 115 S. Ct. 2097 (1995). a more recent affirmative action decision, did not impact or modify the Croson Court's statements regarding Section Five. See id. at 2114 ("It is true that various Members of this Coun have taken different views of the authority $\$ 5$ of the Fourteenth Amendment confers upon Congress . . . and the extent to which courts should defer to Congress' exercise of that authority. . . We need not. and do not. address these differences today.").

The Morgan Court made clear that the only substantial restricuon on Congress's Section Five authority is that enforcement legislation cannot retract or reduce Fourteenth Amendment guarantees "Section 5 is limited to adopting measures to enforce the guarantees of the Amendment; $\$ 5$ granls Congress no power to restrict, abrogate, or dilute" its protectuons. 384 U.S. at 651 n.10. This limuauon clearly does not perain to the VAWA Civil Rights Remedy. Congress's remedy for gender-motusaled violence in no way aims to "restrict, abrogate. or dilute" the equal protecuon guarantees of the Fourteenth Amendment-it only aims to enhance those guarantees.

156. Crimes of Violence, supra note 1, at 45 (statement of Bun Neubome. Professor of Law, Neu York University); see also id. at 63 (statement of Cass R Sunstein. Professor of Law. University of Chicago). Legal scholars generally agree that Congress acting under Section Five can step beyond the judicially defined limits of Section One. See, e.g.. Rober A. Bun. Mirando and Tulle II. A Margananc Marriage, 1969 SUP. CT. REv. 81, 84 ("The Cour is suggesung that. to some extent at least. $\$$ exempts the Fourteenth Amendment from the principle of Cour-Congress relatuonships expressed by Marbury $v$ : Madison, that the judiciary is the final astiter of the meaning of the Constutuonon."): Arehibald Cox. The 
(RFRA) ${ }^{157}$ against claims that its enactment transgressed the boundaries of Section Five, federal appellate courts have confirmed that Congress's Section Five power can reach beyond the parameters of Section One. ${ }^{158}$

According to critics of the VAWA Civil Rights Remedy, the Remedy is unconstitutional because it exceeds the well-defined scope of Section One; they argue that the Remedy's proscription of "purely private conduct" violates the state action requirement of the Fourteenth Amendment. As the Brzonkala court stated in rejecting the Section Five ground of the VAWA Civil Rights Remedy: “[R]emedying private individuals' gender-based crimes is not a legitimate equal protection goal due to the fact that no sufficient state contacts exist." 159 The Brzonkala court, however, conflated the sections of the Fourteenth Amendment; the court repeatedly cited Section One cases for the proposition that the VAWA Civil Rights Remedy surpasses the bounds of Section Five. ${ }^{160}$ In discussing these two Sections as if they were interchangeable, the Brzonkala Court misconstrued Supreme Court precedent that indicates that Section One and Section Five differ in kind and in scope. ${ }^{161}$ As cases like Katzenbach and Morgan demonstrate, in determining the appropriate means of enforcing Section One, Congress is not constrained by judicially proscribed definitions of actionable conduct under Section One. In essence, congressional legislation under Section Five is not restricted to the regulation of activities that in and of themselves would constitute violations of the Equal Protection Clause. Congress therefore has the discretion under Section Five to legislate against private acts of gender-motivated violence, although those private acts would not be actionable under Section One, as long

Role of Congress in Constitutional Determinations, 40 U. CIN. L. REV. 199, 257-59 (1971) (explaining that limiting Congress's Section Five powers to scope of Section One would defeat purpose of enforcement clause and would only enable Congress to replicate what judiciary is bound to do): Bradford Russell Clark, Note, Judicial Review of Congressional Section Five Action: The Fallacy of Reverse Incorporation, 84 COLUM. L. REV. 1969, 1975 (1984) (maintaining that Congress is entitled "to exercise broad discretion to forge remedies in the equal protection context, largely unimpeded by court intervention"); Matt Pawa, Comment, When the Supreme Court Restricts Constitutional Rights, Can Congress Save Us? An Examination of Section 5 of the Fourteenth Amendment, 141 U. PA. L. REV. 1029, 1056 (1993) (positing that under Section Five, "Congress must give force to constitutional rights beyond the perimeters of those rights as defined by the Court").

157. 42 U.S.C. $\$ 2000 \mathrm{bb}$ (1994). The Act reinstated the "strict scrutiny" test for free exercise of religion claims, thereby explicitly overtuming the Supreme Court's nuling in Employment Division v. Smith, 494 U.S. 972 (1990), and rejecting the less stringent standard of review adopted in that case. See 42 U.S.C. $\S 2000 \mathrm{bb}(\mathrm{a})$.

158. See, e.g., Sasnett v. Sullivan, 91 F.3d 1018, 1020 (7th Cir. 1996) (upholding RFRA as constitutionally viable under Section Five and explaining that Congress did not exceed its Section Five powers if legislation at issue "is reasonably designed to secure a right created by the Fourteenth Amendment itself'); Flores v. City of Boeme, 73 F.3d 1352, 1356-61 (5th Cir.), cert. granted, 117 S. Ct. 293 (1996) (stating that Morgan "remains the benchmark" and upholding RFRA because Congress intended to enforce religious liberty protected from state infringement by Fourteenth Amendment).

159. Brzonkala v. Virginia Polytechnic \& State Univ., 935 F. Supp. 779, 799-800 (W.D. Va. 1996).

160. See id. at 797-99 (citing Lugar v. Edmonson Oil Co., 457 U.S. 922 (1982); Flagg Bros., Inc. v. Brooks, 436 U.S. 149 (1978); Shelley v. Kraemer, 334 U.S. 1 (1947)).

161. See supra text accompanying notes $153-55$. 
as those acts are rationally related to the end of enforcing Section One, which prohibits state deprivations of equal protection.

The Brzonkala court's argument that "no sufficient state contacts exist" is flawed in several respects. First, no Supreme Court case suggests that Congress is not constitutionally permitted to reach "purely private conduct" under Section Five when the regulation of private conduct is rationally related to the goal of securing citizens' right to equal protection by the government. In fact, dicta in several Supreme Court cases intimates that Congress is in fact allowed to regulate activities that would not qualify as state action, as long as Congress's overall purpose is to remedy state deprivations of equal protection. Consider, for example, United States v. Guest, ${ }^{162}$ where six Justices agreed that Congress's authority under Section Five is not constrained by the state action principle that applies to Section One case law. ${ }^{163}$ As Justice Brennan stated in his separate opinion in Guest:

I acknowledge that some of the decisions of this Cour . . have declared that Congress' power under $\S 5$ is confined to the adoption of "appropriate legislation for correcting the effects of . . . prohibited State laws and State acts .... I I do not accept-and a majority of the Court today rejects-this interpretation of $\S 5$. It reduces the legislative power to enforce the provisions of the Amendment to that of the judiciary; and it attributes a far too limited objective to the Amendment's sponsors.

.. . I can find no principle of federalism nor word of the Constitution that denies Congress power to determine that in order adequately to protect the right to equal utilization of state facilities, it is also appropriate to punish other individuals-not state officers themselves and not [those] acting in concen with state officers-who engage in the same brutal conduct for the same misguided purpose. ${ }^{164}$

A majority of the Court in Guest was convinced that to enforce the dictates of Section One, Congress must have the power to legislate against purely private conduct if necessary and appropriate in the specific instance. In another Supreme Court decision, District of Columbia v. Canter, ${ }^{165}$ a unanimous Court stated in a footnote that Congress may indeed have the authority under Section Five to reach "purely private conduct": To say that "[t]he Fourteenth Amendment itself 'erects no shield against merely private conduct' . . . is not to say ... that Congress may not proscribe purely private conduct under $\S 5$

162. 383 U.S. 745 (1966).

163. Justice Stewart's plurality opinion in Guest required some showing of publie involvement in order to sustain a congressional exercise of Section Five power. See td. at 75.4-57 (plurality opınion).

164. Id. at 782-84 (Brennan. J., concurring in part and dissentung in part) (footnotes omitted). The six Justices maintaining that Congress can reach private conduct under Section Five were Chief Justuce Warren and Justices Blaci. Douglas, Clark, Brennan, and Fortas.

165. 409 U.S. 418 (1973). 
of the Fourteenth Amendment."166 In view of the ambiguity of case law on the subject, Harvard Law Professor Laurence Tribe stated in his treatise on constitutional law that the question of whether Congress can regulate "purely private conduct" under Section Five remains unanswered. Professor Tribe explained that, "the Court has had no occasion to confront the extent to which the state action requirement limits congressional power to enforce the fourteenth amendment." ${ }^{167}$ Because the issue of whether Congress can reach "purely private conduct" is yet unresolved, it is incorrect for the Brzonkala court and other challengers of the VAWA Civil Rights Remedy to assume that Congress has exceeded its authority under Section Five in legislating against private acts of gender-motivated violence in an effort to enforce the Equal Protection Clause.

Of course, it is important to recognize that although Congress appears free to regulate "purely private conduct," there must exist "sufficient state contacts" so that the regulation truly remedies state denials of equal protection. In the Civil Rights Cases, ${ }^{168}$ one of the earliest Supreme Court decisions establishing the extent of Congress's power under Section Five to enforce the terms of the Fourteenth Amendment, the Court invalidated several sections of the Civil Rights Act of 1875 , which, without "reference whatever to any supposed or apprehended violation of the Fourteenth Amendment on the part of the States," 169 required that states provide all citizens equal accommodation and privileges at inns, public conveyances, and places of public amusement. The Court struck down the statute because it had no apparent connection to state action of any kind:

[C]ivil rights, such as are guaranteed by the Constitution against State aggression, cannot be impaired by the wrongful acts of individuals, unsupported by State authority in the shape of laws, customs, or judicial or executive proceedings. The wrongful act of an individual, unsupported by any such authority, is simply a private wrong, or a crime of that individual ... if not sanctioned in some way by the State .... ${ }^{170}$

Because the VAWA Civil Rights Remedy is rooted in state denials of equal protection, it meets the standard established in the Civil Rights Cases. Although the VAWA Remedy reaches the "wrongful acts of individuals," its legislative history demonstrates that the granting of a remedy for those

166. Id. at 423-24 \& 424 n.8 (quoting Shelley v. Kraemer, 384 U.S. 1, 13 (1948)).

167. LAURENCE H. TRIBE, AMERICAN CONSTITUTIONAL LAW $\$ 5-15$, at 351 ( $2 \mathrm{~d}$ ed. 1988). Note that even the Brzonkala court conceded: "Some authority indicates that Congress may address purely private conduct via $\S 5$ of the Fourteenth Amendment in spite of the fact that $\$ 1$ actions require state action." Brzonkala v. Virginia Polytechnic \& State Univ., 935 F. Supp. 779, 794 (W.D. Va. 1996).

168. 109 U.S. 3 (1883).

169. Id. at 14 .

170. Id. at 17. 
wrongful acts is predicated on laws and customs that do not effectively protect victims of gender-motivated violence. ${ }^{71}$ Because states have failed to provide and administer laws to safeguard female crime victims, private acts of gender-motivated violence are undoubtedly, in the words of the Civil Rights Cases Court, "sanctioned in some way by the state."

The inquiry as to whether Congress exceeded its Section Five powers does not end here, however. Section Five of the Fourteenth Amendment explicitly states that Congress has the power to enforce Section One by "appropriate legislation." "173 The Morgan Court, following the McCulloch v. Maryland ${ }^{178}$ standard, interpreted this provision to include legislation that is " "plainly adapted' to furthering the[] aims of the Equal Protection Clause."175 As the following discussion makes clear, there is no question that the VAWA Civil Rights Remedy is "appropriate legislation" within the meaning given by the Morgan Court.

Several aspects of the VAWA Civil Rights Remedy illustrate the fact that the statute was specifically designed to remedy equal protection problems. First, the Remedy appropriately addresses the type of violence most frequently suffered by women. It is well established that most violence against women occurs in private and is perpetrated by people known to the victim. ${ }^{176}$ In contrast to race-based discrimination, acts of gender-motivated violence are not usually committed under color of state law $^{17}$ or by a conspiracy of

171. See infra Section II.A.

172. 109 U.S. at 17.

173. U.S. CoNST. amend. XIV, \& 5 (emphasis added).

174. 17 U.S. (4 Wheat.) 316,421 (1819).

175. Katzenbach v. Morgan, 384 U.S. 641. 651-52 (1966). One academic commentator desenbing the Morgan standard for "appropriate legislation" explained that "the Courn should accord Congress broad discretion to pursue its chosen means. Only when Congress has clearly mistaken the effectiveness of its means for furthering valid ends should the Cour strike down Congress" selected remedy. "Clark, supra note 156, at 1986.

176. According to the Department of Justice's most recent Nastonal Crime Vicumtzatton Survey. approximately $75 \%$ of all lone-offender violence agannst women is perpetrated by an offender whom the victim knows. See BaCHMAN \& SALTZMaN, supra note 3. al 1. Furthermore, in $29 \%$ of all violence aganst women by a lone offender, the perpetrator is a husband, ex-husband, boyfnend, or ex-boyfriend-an intimate. See id; see also Violence Against Women: Relevance for Medical Practurners. J AM. MED. Ass'N, June 17, 1992, at 34 (reporting that women are more likely to be assaulted, raped, or killed by current or former male partners than by all other types of assailants combuned, and that vicums of volence by intimates are much more likely to be reassaulted within six months than votums of volence by nonintimates).

177. Section 1983 provides a civil rights cause of actuon aganst every person who. acung under color of state law, deprives a citizen of "any rights, privileges, or immunitues secured by the Consutution and laws." 42 U.S.C. \& 1983 (1994). In addition to, and prior to the existence of. the VAWA Civil Rights Remedy, a victim of gender-motivated violence could bnng a section 1983 suit in response to a state law or policy that denied her equal protection of the laws. In Personnel Administrator of Massachuserts $v$ Feeney, 442 U.S. 256 (1979), however, the Court held that a plainuff alleging that a facially neutsal statc law or policy discriminates on the basis of gender must prove the existence of a deliberate intent to discriminate. See id. at 274. Because discriminatory purpose is so difficult to establish. section 1983 has not been an effective means of challenging state laws and practices that discriminate agannt women. See. e.g., Eagleston v. Guido, 41 F.3d 865, 878 (2d Cir. 1994) (holding that statistics establishıng that vicums of domestic violence were treated differently than victims of other violence with respect to type of police response and likelihood that arrest would be made did not show section 1983 equal protection violation 
wrongdoers. ${ }^{178}$ Because existing civil rights laws were drafted primarily to address the problem of racial discrimination, these laws do not respond in any significant way to the problem of gender-motivated violence. As Representative Patricia Schroeder explained at the VAWA legislative hearings: "Gender motivated violence cannot be adequately affected by existing civil rights structures because gender crimes manifest themselves differently than other crimes-they tend to be acts by individuals." 179 Clearly, a meaningful and effective civil rights remedy for victims of gender-motivated violence must reach violence committed by individuals acting in a private capacity. Because the VAWA Remedy is the first civil rights statute to recognize what constitutes the most common and devastating threat to women's equal citizenship, it is true to its purpose of enforcing the Equal Protection Clause.

The VAWA Civil Rights Remedy also effectively remedies the problem of equal protection at the state level by simply offering an alternative, less biased forum for victims of gender-motivated violence. First, plaintiffs bringing suit in federal court do not have to contend with unjust and outmoded laws, such as the marital rape exemption and the fresh complaint rule, which still exist in a number of states. ${ }^{180}$ Second, although gender discrimination undoubtedly exists in the federal system as well, there is evidence that female victims of violence have received fairer treatment in federal court. ${ }^{181}$ The very fact that the VAWA Civil Rights Remedy offers a federal forum for victims of gender-motivated violence, along with the fact that the Remedy specifically addresses the most frequent and harmful kind of violence against women, leads to the inevitable conclusion that the VAWA Remedy is

absent evidence showing impermissible discriminatory intent); Paiewonsky v. Paiewonsky, 446 F.2d 178, 181-82 (3d Cir. 1971) (upholding interspousal immunity doctrine against equal protection challenge). Legal academics have noted that section 1983 is an inadequate solution to the problem of gender-motivated violence. See, e.g., Developments, supra note 122, at 1567-71 (describing difficulties of bringing genderbased equal protection claims under Feeney standard).

178. Section 1985 provides federal civil rights protection against a "[c]onspiracy to interfere with civil rights." 42 U.S.C. \& 1985 (1994). The 1995 National Crime Victimization Survey reports that only 16\% of violent victimizations against women are committed by multiple offenders. See BACHMAN \& SALTZMAN, supra note 3 , at 2 . In comparison, $27 \%$ of violent victimizations against men are perpetrated by multiple offenders. See id.

179. Crimes of Violence, supra note 1, at 95 (statement of Rep. Schroeder); see also id. at 10 (statement of Sally Goldfarb, Senior Staff Attorney, NOW Legal Defense and Education Fund) (explaining that VAWA Remedy is necessary "because gender-based violence typically differs from the types of racial violence directed against men"); Andrea Brenneke, Civil Rights Remedies for Battered Women: Axiomatic \& Ignored, 11 LAW \& INEQ. J. 1, 44-53 (1992) (arguing that existing civil rights remedies fail to protect battered women); Hallock, supra note 16, at 592 ("The civil rights legislation currently in force in the United States is inadequate for addressing the problem of violent gender-based discrimination . . ...").

180. See supra text accompanying notes 124-32.

181. See 9th Circuit Studies Gender Bias, A.B.A. J., Nov. 1992, at 30 (reporting that "the federal courts are relatively free of the kind of blatant sexism [women] have encountered in some state courts"); Hallock, supra note 16, at 601 ("[A]s with civil rights legislation aimed at protecting racial minorities, it is fair to assume that the federal system would provide litigants a better opportunity to assert their rights than would state courts."). 
"appropriate legislation" to further the aims of the Section One of the Fourteenth Amendment.

\section{CONCLUSION}

Gender-motivated violence is a federal problem that warrants a federal solution. Although the constitutional bases of the VAWA Civil Rights Remedy have been and are expected to be fiercely contested, Congress most likely acted within its authority under both the Commerce Clause and Section Five of the Fourteenth Amendment. Because gender-motivated violence deeply affects interstate commerce, the VAWA Civil Rights Remedy should survive the ambiguous threat posed by Lopez. Moreover, the VAWA Remedy is firmly supported on another constitutional ground: It is an appropriate and effective means of enforcing the Equal Protection Clause, and fits within the scope of Congress's power under Section Five of the Fourteenth Amendment.

If gender-motivated violence continues unabated by a federal remedy, women will continue to be deprived of their full citizenship rights. State law as currently enforced does not provide victims of gender-motivated violence the full rights of citizenship; victims are frequently denied equal protection of the laws by many state criminal justice systems. Moreover, unassisted victims of violence cannot participate on an equal basis in the national economy; their contribution to interstate commerce decreases and consequently, in Sally Goldfarb's words, "our entire society is diminished." 182 As two parts of the same equation, the Commerce Clause and Section Five bases of the VAWA Civil Rights Remedy are both necessary' and appropriate means of achieving full and equal citizenship.

182. See Crimes of Violence, supra note 1 , at 8. 
